Linköping Studies in Science and Technology

Dissertation No. 2056

Advancement of sensor technology for

monitoring and control of upstream bioprocesses

Judit Randek

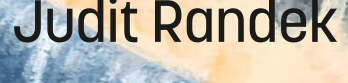


Linköping Studies in Science and Technology

Dissertations, No. 2056

\title{
Advancement of sensor technology for monitoring and control of upstream bioprocesses
}

\author{
Judit Randek
}

\author{
Linköping University \\ Department of Physics, Chemistry and Biology \\ Division of Biotechnology \\ SE-581 83 Linköping, Sweden
}

Linköping 2020 
About the cover: Illustration of E.coli and S.cerevisiae cells together with a near-infrared and a capacitance sensor (not scale).

During the course of the research underlying this thesis, Judit Randek was enrolled in Forum Scientium, a multidisciplinary doctoral programme at Linköping University, Sweden.

C Copyright 2020 Judit Randek, unless noted otherwise

Randek, Judit

Advancement of sensor technology for monitoring and control of upstream bioprocesses

ISBN 978-91-7929-881-4

ISSN 0345-7524

Printed by LiU-Tryck, Linköping 2020 


\section{Abstract}

In bioprocesses, the upstream process part with cultivation and harvesting steps has decisive influence on the final process outcome, including the quality of the product, the productivity and the yield. To ensure stable product quality of biopharmaceuticals, the U.S. Food and Drug Administration (FDA) encourages the industry to apply the process analytical technology (PAT) guidelines. These guidelines strongly recommend advancements in sensor monitoring and control technology as the important means for improving performance of pharmaceutical manufacturing.

The aim of this thesis is to contribute to this advancement of sensor technology, by proposing alternative ways to apply existing sensors for monitoring and control of upstream bioprocesses.

Cutting-edge sensor technologies are evaluated with respect to their suitability for process monitoring of critical process parameters. The sensor technologies are compared with other analytical techniques, mainly based on their performance and applicability for monitoring as well as control of common bioprocesses.

To cover diverse bioprocess conditions and requirements, a range of organisms, including bacteria, yeast and mammalian cells, have been used in the thesis. Through this, different needs, obstacles and challenges have been unraveled when culturing these organisms. One of these challenges is the wide span of growth rates of the cells used in production, which limits the number of the sensor technologies that are suitable for accomplishing efficient process monitoring and control.

The mammalian cells for example, grow at a low rate, and may therefore allow the use of an at-line measurement technology as the presented screen-printed single-use enzyme biosensor for monitoring of metabolite formation. On the contrary, rapidly growing microorganisms, for example bacteria and yeasts, require 
faster analytical techniques, such as the in-line capacitance and nearinfrared sensors used in the presented studies.

This thesis emphasizes the current needs and the importance of providing new and more advanced sensor technology for upstream bioprocess monitoring. The parallel advancements of bioreactor designs, with both stainless steel and disposable bioreactors, further emphasizes the need for a high degree of adaptability of the sensors. As highlighted in the thesis, the advancement of the sensors should also contribute to improve process stability and quality of the product by applying process control methods that efficiently can handle unexpected variations in biological production systems. 


\section{Populärvetenskaplig sammanfattning}

Biotekniska processer svarar för att förse samhället med en rad viktiga produkter inom läkemedels-, livsmedels-, och bioenergiområdena. Det största intresset idag åtnjuter de biologiska läkemedlen som står för en betydande del av utvecklingen av nya läkemedel. För att säkerställa att läkemedel har stabil och hög kvalitet har det amerikanska läkemedelsverket (FDA) utfärdat en rad riktlinjer för läkemedelsproduktion som man benämner Process Analytical Technology (PAT). I riktlinjerna rankar man processövervakning och processkontroll som de främsta medlen för att nå hög produktkvalitet. Särskilt uppmanar man läkemedelsindustrin att utnyttja effektivare sensorteknologi för att öka produktionens säkerhet men också för att förbättra förståelsen för vad som händer i produktionsprocessernas olika delsteg. Vid produktion av biologiska läkemedel är det viktigt att förbättra kunskapen om de celler som används för att kunna uppnå målen i PAT. För att lyckas med det behöver man utveckla de sensorteknologier som används idag och anpassa dem bättre till de biologiska produktionsprocessernas förhållanden.

I avhandlingen görs inledningsvis en noggrann jämförelse av de sensorer som i dag är utvecklade för processövervakning med syftet att hitta de som är mest lämpade för syftena med PAT. Några av dessa har sedan utvalts och testats närmare för processövervakning i odlingskulturer som ofta används vid läkemedelsproduktion. Vid kulturer som används bl.a. för antikroppsproduktion är bildning av laktat en viktig parameter som behöver övervakas i produktionsprocessen. Detta har i avhandlingen lösts genom att först utveckla en enzymbaserad engångssensor och sedan testa den $\mathrm{i}$ produktionsmiljö. 
Morfologiska förändringar i produktionsorganismerna, exempelvis genmodifierade bakterier och jästceller, kan ha negativa effekter på cellernas produktivitet och överlevnadsförmåga. Det är därför viktigt att kunna mäta och identifiera sådana förändringar. I avhandlingen har det gjorts genom att analysera frekvensspektra från en kapacitanssensor som får mäta cellerna vid olika produktionstillstånd.

Ett viktigt syfte med processövervakning är att använda informationen för att styra bioprocessen och på så vis säkerställa stabil produktkvalitet. I avhandlingen visas hur man kan använda en kontinuerlig sensor för att mäta cellers koncentration med infrarött ljus för att följa cellernas tillväxthastighet. Detta ligger till grund för en återkopplad reglering av cellernas tillväxt i produktionsprocessen. Arbetena som presenteras i avhandlingen spänner över de steg som PAT riktlinjerna rekommenderar - från design av mätsystem till processkontroll - och bidrar på så sätt att få ytterligare förståelse för bioprocesser och för hur man kan uppnå stabil produktivitet och produktkvalitet av biologiska läkemedel. 


\section{List of publications}

This thesis is based on the following publications:

Paper I

J Randek J, CF Mandenius

On-line soft sensing in upstream bioprocessing Critical Review in Biotechnology 2018, 38, 106-121

Contribution: Performed background research and analysis. Wrote the article in collaboration with the co-author.

\section{Paper II}

J Randek J, CF Mandenius

In situ scanning capacitance sensor with spectral analysis reveals morphological states in cultures for production of biopharmaceuticals Sensors and Actuators B: Chemical 2020, 313, 128052

Contribution: Conceived and done all experimental research and analysis presented in the article. Wrote the main part of the manuscript.

\section{Paper III}

J Randek J, M Enqvist, CF Mandenius

Using an in-line near-infrared sensor for control of specific growth rate in a fed-batch cultivation producing recombinant protein

Submitted 2020

Contribution: Conceived study, designed and conducted all experiments presented in the manuscript and troubleshot with M.E.. Wrote the main part of the manuscript. 


\section{Paper IV}

J Randek J, CF Mandenius

The feasibility of monitoring morphological changes of yeast cells using in-situ capacitance sensor spectra

Submitted 2020

Contribution: Conceived and performed all experimental research and analysis presented in the manuscript. Wrote the main part of the manuscript.

\section{Paper V}

L Threuer, J Randek, S Junne, P Neubauer, CF Mandenius, V Beni

Single-use printed biosensor for L-lactate and its application in bioprocess monitoring

Processes 2020, 8, 321

Contribution: Participated in planning and performed experimental work with mammalian cells. Participated in writing and editing of the article together with the co-authors. 


\section{List of abbreviations}

CER Carbon-dioxide evolution rate

$\mathrm{CHO}$ Chinese hamster ovary

CPP Critical process parameter

CPV Continued process verification

CQA Critical quality attribute

DCW Dry cell weight

DO Dissolved oxygen

FAD Flavin adenine dinucleotide

FDA Food and Drug Administration

GC Gas chromatography

GFP Green-fluorescent protein

HPLC High performance liquid chromatography

$\mathrm{ICH}$ International Council for Harmonisation of

Technical Requirements for Pharmaceuticals

for Human Use

IPA Isopropyl-alcohol

IPTG Isopropyl $\beta$-D-1-thiogalactopyranoside

$\mathrm{LDH} \quad$ L-lactate dehydrogenase

LOD L-lactate oxidase

$\mathrm{mAb}$ Monoclonal antibody

NIR Near-infrared

OD Optical density

OPC Open Platform Communications

PAT Process analytical technology

PET Polyethylene terephthalate

PID Proportional-integral-derivative

SEM Scanning electron microscope

SPC Statistical process control

USP Upstream (bio)process 



\section{Acknowledgements}

I would like to thank my supervisor, Carl-Fredrik Mandenius for your guidance and the opportunity to work in this exciting and challenging project through I stretched my boundaries.

Thanks to my co-workers at the Division of Biotechnology; Robert, Jonas and Patricia for all your help and support in the lab over the years.

I am deeply grateful to my mentor, Thomas Ederth who supported me throughout my studies.

I wish to express my deepest gratitude to Martin Enquist for our discussions and your unwavering guidance during this last year.

I would like to thank to the members of BIORAPID for making this project such a unique experience. Especially, I wish to thank Lorenz and Valerio for our work together and to Matthias and Alex for the possibility of working in their lab and all the support they gave me during this time.

Thank you for the members of Forum Scientium including Stefan, Charlotte and Anette for the inspiring environment of the graduate school.

I would like to thank all my friends at IFM for their continuous support and love, it helped me through my worst days. Especially to Víctor, Alex and Andreas for always cheering me up with their optimism and joy.

Many thanks for everyone involved in the Wednesday boardgame nights and for the members of the squash club who made my life fun outside of work; it has been delightful to play with you all.

Thanks to Vanessa and Andy for all the great time we had together.

Un grand merci à Marie-Noelle, Luçay et Isabelle qui ont m'aidé avec leur amour et leur soutien à continuer même les jours difficiles.

Hatalmas köszönet a nagyszüleimnek és a testvéreimnek, hogy bármikor felhívhattam őket, ha bátorításra vágytam! Köszönöm Bencének, Kirának és Noelnek, hogy vidámságukkal szebbé tették az otthon töltött napjaim! Külön köszönöm Apának az évek során adott tanácsait és azt, hogy elindított ezen az úton!

A special thank you for Kevin for all his support, for all of our fantastic trips and for showing me that everything is a lot easier if I can turn it to fun. 



\section{Contents}

$\begin{array}{ll}\text { Abstract } & \text { i }\end{array}$

Populärvetenskaplig sammanfattning iii

List of publications $\quad \mathbf{v}$

Abbreviations viii

$\begin{array}{ll}\text { Acknowledgments } & \text { ix }\end{array}$

Contents $x i$

1 Introduction 1

1.1 Aim and scope of the thesis . . . . . . . . . 1

2 The necessity of monitoring and control in bioprocesses 3

2.1 The width of production organisms and products in industrial biotechnology . . . . . . . . . . . 3

2.1 .1 Escherichia coli . . . . . . . . . . . . . . 4

2.1.2 Saccharomyces cerevisiae . . . . . . . . . . . 5

2.1.3 Mammalian cells ... . . . . . . . . . 6

2.2 Unity and diversity in recombinant protein production 7

2.2.1 Fed-batch mode as the dominating cultivation strategy ................ 8

2.2.2 Differences in the cultivation processes due to the diversity in host organisms . . . . . . . . 9

2.3 Current trends, needs and expectations in the bioindustry 11

3 State-of-the-art of bioprocess monitoring 
3.1 Process analytical technology as a drive for advancement of bioprocess monitoring . . . . . . . .

3.2 Monitoring of the bioreactor: standard and advanced methods ...................

3.2.1 Consequences of diversity of production systems for monitoring . . . . . . . . . . . 14

3.2.2 Standard and advanced monitoring . . . . . . 17

4 Implementing monitoring methods for bioprocess control

4.1 Adaptation of monitoring techniques to improve control 21

4.2 Control methods in bio-industrial practice . . . . . . 22

4.2.1 Feed-forward and feedback control in fed-batch processes................... 22

4.2.2 Feedback control solutions . . . . . . . . . . 24

4.3 Validation of bioprocesses . . . . . . . . . . 26

5 From single-use to in-line: monitoring methods exploited in this thesis in theory and practice

5.1 Rapid, low-cost monitoring of key metabolites to provide CPP data just-in-time . . . . . . . . . . . .

5.2 Extracting additional information on morphological state of the cells by combining monitoring methods . .

5.3 A concept to advanced bioprocess control: absorbance sensor for monitoring and control the growth of biomass in a bioreactor . . . . . . . . . . . .

6 Conclusion and future perspectives

References

51 


\section{Chapter 1}

\section{Introduction}

Biotechnology is the application of biological systems and organisms to technical and industrial processes [1]. This is done since thousands of years, started by the brewers and bakers in the ancient Egypt, continued by Anton van Leeuwenhoek's discovery on the existence of microorganisms till today's improvement on human gene editing. The fastest developing field of biotechnology is industrial biotechnology. With its highlights of pharmaceutical bioprocesses, the field developed from Pasteur's rabies vaccine to genetic-based personalized medicine in less than 150 years. Significant improvements have been made in the production of pharmaceuticals - nowadays several medicine, including vaccines, are produced by genetically modified organisms instead of animals - and thank to the increasing knowledge on production processes, the risk of serious illness caused by the impurities present in the medicine is minimized.

To be able to ensure safe production of pharmaceuticals, the parameters that influence its quality must be followed and if possible controlled. This can be achieved by developing new monitoring methods and exploring alternative uses of the existing techniques that can provide additional insight into the processes and ensure constant product quality.

\subsection{Aim and scope of the thesis}

The aim of this thesis has been to contribute to the advancement of sensor technology for monitoring and control of upstream bioprocesses 
by proposing alternative applications of already existing sensors. The first chapter provides a brief introduction to bioprocesses and presents the aim and scope of the thesis. The biological systems used in this thesis to test and demonstrate the advancements of the sensor technologies are described in detail in the second chapter, where their similarities, differences and needs in terms of production system and recombinant protein production are highlighted. The third chapter explains the driving forces behind the needs for improvements of monitoring in bioprocesses, and provides an insight into the state-ofthe-art of monitoring tools from off-line to in-line, indicating their importance and advancement. The fourth chapter discusses the needs and the possible applications of these monitoring techniques in bioprocess control together with the difficulties and challenges that are met with various control approaches. The theory and practice of the sensors that have been applied during the studies are described in depth in the fifth chapter. Besides presenting the traditional way of their use, the potentials for advancements with these sensor techniques are also highlighted. Finally, the sixth chapter provides the concluding remarks of the findings in the thesis and discusses future perspectives of their applications.

The presented research and findings demonstrate the advancement of several sensor technologies in upstream bioprocesses, and these sensors' contributions to process improvements and better process stability in compliance with the demanding regulatory guidelines of biopharmaceutical production. The careful mapping of pros and cons of available sensor technologies that can help to identify the most suitable techniques for the varying needs of bioprocesses were outlined (Paper I). In the thesis, these methods were verified in upstream processes with bacterial, yeast and mammalian cultures. The approaches included a selection of sensors from the single-use screenprinted biosensor capable of monitoring lactate formation (Paper V) to the in-line capacitance sensor offering the possibility to identify morphological changes of cells (Paper II and IV). Finally, a controller concept based on a turbidity sensor was exploited to control the growth rate of cells in recombinant protein production (Paper III). 


\section{Chapter 2}

\section{The necessity of monitoring and control in bioprocesses}

\subsection{The width of production organisms and products in industrial biotechnology}

Pharmaceutical bioprocesses are used to manufacture different medical products including enzymes, antibiotics and vaccines. During the upstream part of the process, the cells are cultured in a bioreactor and express the target product. However, this product must go through several purification steps of the downstream process before it is ready to be injected into patients.

In upstream bioprocesses (USP), a wide variety of cells from bacteria and yeasts to mammalian cells are used to produce biopharmaceutical products. These cells are very different physiologically and they have quite diverse needs for growth and production. Consequently, they are accompanied with various strengths and weaknesses when considered for industrial use.

While mammalian cells have gained a dominating place in industry during the last twenty years, Escherichia coli and Saccharomyces cerevisiae have remained the two most widely used microorganisms until today [2]. 


\subsubsection{Escherichia coli}

Escherichia coli is a $2 \mu \mathrm{m}$ long, rod-shaped bacterium with a cell volume of $0.6-0.7 \mathrm{\mu m}^{3}$. It reproduces through cell division by duplicating its chromosomal genes, or through conjugation and pilus transfer of its genetic material. As one of the fastest growing microorganisms, it has a generation time as short as 20 minutes in some of its sub-strains.

Its growth can be driven both by aerobic and anaerobic respiration. While the aerobic growth is supported on a variety of carbon sources besides glucose such as glycerol, pyruvate, succinate and acetate [3], the anaerobic growth is associated with mixed acid fermentation metabolism. Here, also the metabolites from these pathways (e.g. lactate, succinate, ethanol and acetate) can be consumed by the cells but they exert inhibition of the anaerobic growth as well.

Many important biopharmaceutical proteins are expressed by E. coli [4]. The first recombinant protein produced industrially was human insulin [5] which was followed by human growth hormone, $\alpha, \beta, \gamma$-interferons, granulocyte-colony stimulating factor (G-CSF), pertussis and cholera toxin [6].

The expression systems transferred by genetic engineering into E. coli are typically based on self-replicating multicopy plasmids containing the coding genes of the target product and regulated by strong promoters. One of the most commonly used promoters is T7 which can be either transferred into the cells using plasmid or directly integrated into the bacterial genome [7]. With this promoter the recombinant protein expression can be induced by isopropyl $\beta$-D-1thiogalactopyranoside (IPTG).

$E$. coli has several advantages when used for recombinant protein production. Its low-cost cultivation, well-known genetics, easy transformation, high cell density, high product yield and growth rate make it often a favourable choice [8]. The recombinant proteins are however formed without glycosylation. Thus, glycosylated proteins such as full-length antibodies cannot be produced by it due to the risk of immunogenic response, but smaller proteins and antibody fragments are expressed industrially $[9,10]$.

A serious disadvantage with recombinant expression in E. coli is that proteins produced at high concentrations often form insoluble protein aggregates, so-called inclusion bodies (Figure 2.1) [11]. The inclusion bodies appear at the polar regions of the cell and may provoke abnormal cell division, accompanied by formation of clustering and 
2.1. The width of production organisms and products in industrial biotechnology

filamentation of the cell [12-14]. These abnormalities during growth would be of great value to monitor in industrial processes with the purpose to limit their negative effects, such as reduced cell concentration and growth rate of the host cells, decreased protein productivity, endangered product quality and cell death $[13,15]$.

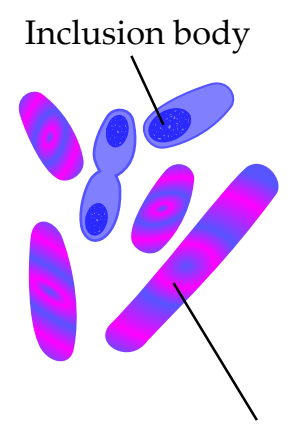

Abnormal morphology

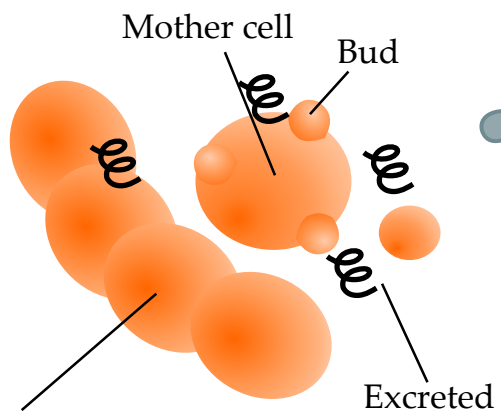

recombinant protein

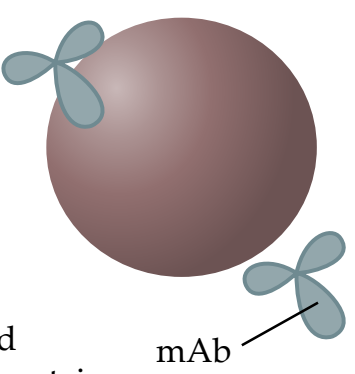

$\mathrm{mAb}$

\section{Escherichia coli Saccharomyces cerevisiae Mammalian cell}

Figure 2.1: E. coli, S. cerevisiae and mammalian cells with their protein expression.

\subsubsection{Saccharomyces cerevisiae}

The yeast Saccharomyces cerevisiae is a round/ovoid shaped eukaryotic cell with a diameter of 5-10 $\mu \mathrm{m}$. As E. coli, S. cerevisiae can reproduce either sexually or asexually. Under stress conditions (e.g. starvation), the cells enter sexual reproduction leading to mating of different haploid spores. In an optimal environment, the cells reproduce asexually by budding. During budding, a genetically identical small bud (or daughter cell) is formed on the mother cell which grows until the bud separates from the mother cell, thereby creating a new yeast cell (Figure 2.1). This growth behaviour results in a doubling of the yeast population within 100 minutes under favourable conditions.

Yeast cells change their size and morphology due to several reasons, including reproduction [16], osmotic stress [17] and lack of nutrients [18]. Although some of these changes support the cells' survival, during industrial applications they can often also lead to serious consequences, such as abnormal or blocked cell division, lower cell 
concentration, productivity and growth rate. Thus, it is of great interest to monitor and, if possible, prevent conditions where abnormal cell growth is triggered.

The metabolism in S. cerevisiae is either oxidative or fermentative or a mixture of these. The oxidative metabolism is the result of low carbon source concentration in the culture media in presence of oxygen, while oxygen-depleted or glucose-elevated conditions cause the cells to enter the fermentative pathway. During fermentative metabolism, several inhibitive metabolites such as ethanol and acetaldehyde are formed. These already at lower concentrations decrease the growth rate, and in higher concentrations can lead to cell death.

Yeast cells exhibit all the advantages of recombinant protein expression present in E. coli, justifying their importance in the production of pharmaceuticals, such as human serum albumin, $r$ hirudin, tetanus toxin and hepatitis B antigen (r HBsAg) [6]. Furthermore, yeast cells show better genetic stability, a more controlled secretion and the ability to carry out complex post-translation modifications [2].

Although yeast cells grow slower and have a lower product yield than bacteria, the expressed proteins are correctly folded and can have complex post-translational modifications. Their ability to direct the produced protein to either be accumulated in the cytoplasm or excreted to the media facilitates the downstream processing compared to proteins expressed as inclusion bodies by E. coli.

\subsubsection{Mammalian cells}

Mammalian cell cultures for production of biopharmaceuticals are based on immortalized cell lines. They were first introduced into the industry during the 80 's triggered by the need of producing glycosylated proteins that could not be produced by E. coli [19]. The most commonly used mammalian cells in industrial applications are the Chinese hamster ovary ( $\mathrm{CHO}$ ) cells, the baby hamster kidney (BHK) cells, the SF-9 (insect cell line) and the human embryonic kidney (HEK) cells.

The cells from these cell lines are by size the largest host cells used in industrial production systems with a cell diameter in the range of 10-50 $\mu \mathrm{m}$ (Figure 2.1). They have modest growth rates with a doubling time between 24 and 48 hours. Due to their size and membrane structure, they are extremely sensitive to shear stress, which makes aeration and mixing a critical issue in large-scale bioreactors. 
During growth, these cell lines have a profound tendency to produce a high amount of lactate as a side-product which decreases the growth rate and the viability of the cells, and lower their recombinant protein pruduction [20]. To reduce the lactate formation, media with alternative carbon sources and low glucose concentration were developped [21, 22].

Although productivity in mammalian cell cultures is lower than in $E$. coli and yeast, the recovery yield of the product is normally higher. The recombinant protein is generally excreted from the mammalian cells into the culture media and compatible with the human immune system due to the right folding, glycosylation and phosphorylation patterns. These advantages eliminate several downstream steps that lead to the loss of yield in microbial processes, such as cell disintegration, extraction, renaturation and refolding [23].

During the last twenty years, biopharmaceutical proteins approved for production in mammalian cells have increased from $55 \%$ to $79 \%$. This have included well known proteins such as erythropoietin, thrombin, various clotting factors (VIII, IX) and different monoclonal antibodies (mAbs) $[24,25]$.

These pharmaceuticals are expensive due to the long cultivation times of the mammalian cells, the high cost of media and supplements, and other manufacturing costs. The use of undefined media components, for example bovine and human sera, further increases the costs besides introducing a high virus contamination risk [26]. Today, a few welldefined serum-free media are available that provide safe alternatives for recombinant protein production [27].

\subsection{Unity and diversity in recombinant protein production}

Most of the industrial bioprocesses run in fed-batch mode, where a feed containing the nutrients essential for the cells is continuously or semi-continuously pumped into the bioreactor (Figure 2.2a). Besides the withdrawal of samples for analysis, no media or cells are removed from the culture until the end of the process. 


\subsubsection{Fed-batch mode as the dominating cultivation strategy}

The recurrent use of fed-batch procedures in bioprocessing can be explained by three reasons: the feeding scheme may serve as a way (1) to metabolically control the growth of the cells, (2) to avoid depletion of oxygen by limiting the rate of growth through controlled oxygen transfer in relation to the bioreactor and (3) to overcome substrate inhibition [28]. Thus, the fed-batch can deal both with the high oxygen demand of bacteria and the substrate inhibition effects in yeast and other cells.

a)

b)

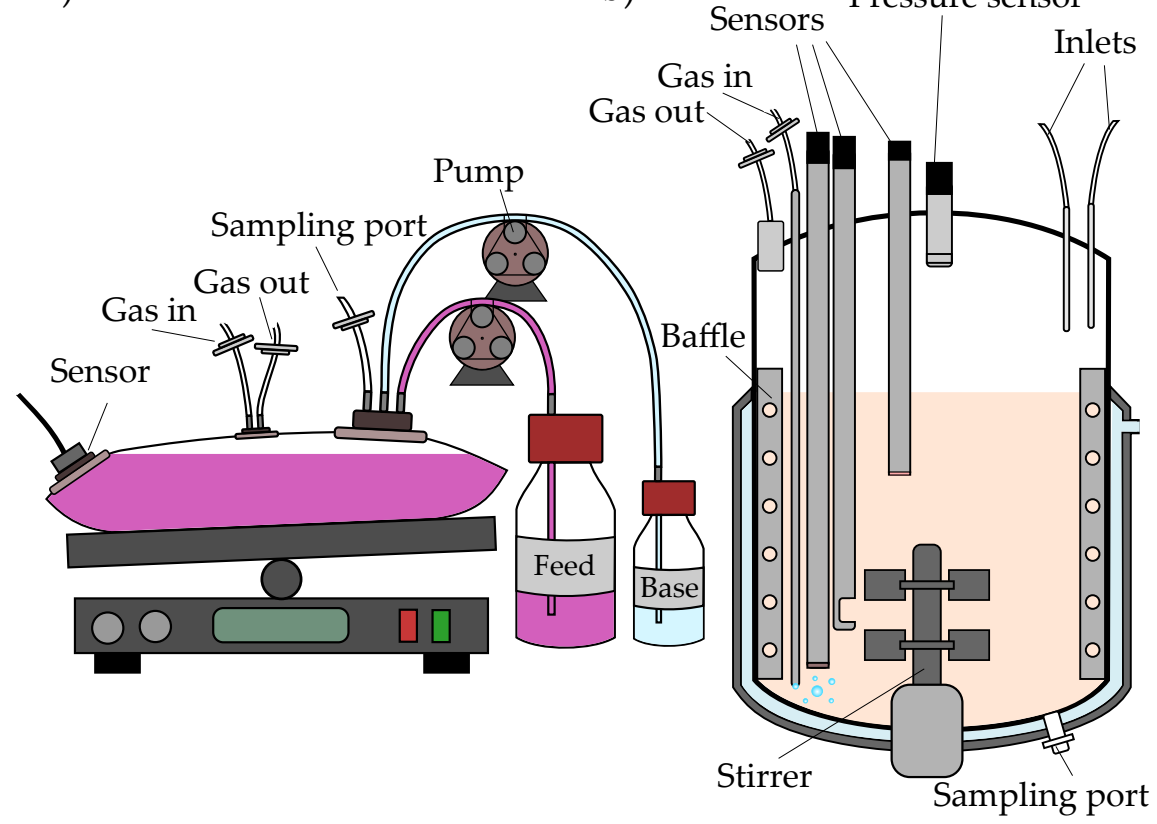

Figure 2.2: The two different reactor types: (a) the single-use bioreactor bag and (b) the stainless-steel bioreactor.

The feed-profile can be constant, increasing (linearly or stepwise) or exponential, each offering different growth control possibilities. Although a good supply of nutrients can be ensured by linear feeding, the ideal feeding scheme is exponential. As the cells grow exponentially, a constant growth rate of the cells can only be achieved by providing the substrate according to an exponential curve. This is the basic control method used in bioprocesses. 


\subsubsection{Differences in the cultivation processes due to the diversity in host organisms}

Thirty years ago, the stainless-steel bioreactors were the only alternative for recombinant protein production for both microbial and mammalian cells. Nowadays, microbial cells are still cultured in the stainless-steel reactors, while the single-use bioreactors have become more or less the standard cultivation platform for mammalian cells (Figure 2.2). The single-use reactors have significantly contributed to eliminate the potential contamination risks and allowed a greater degree of adaptation to the varying needs and characteristics of the mammalian hosts in comparison to microbial cultures.

Microbial cells require extensive aeration and mixing to provide enough oxygen for rapid growth and to avoid growth inhibiting metabolite formation (acetate, ethanol). Stainless-steel bioreactors, even with high volumes (5-25000 L), can cope with these requirements and maintain high density cultures through the efficient aeration and cooling system. These reactors are also robust for use in industrial environments, have a high capacity for including supply systems and can be equipped with several media supply lines (cooling water, steam, gas). By integrating them with various sensors, the monitoring and control of limiting substrate concentrations in the media and the growth rate of the cells becomes possible. Although microbial cultivations have a lower risk of contamination than mammalian cell cultures (Table 2.1), several risks can still be mentioned: the improper handling of connections to pipes and sensors, the contamination due to O-ring misplacement, the not high-enough sterilization temperature or the inefficient cleaning. 
Table 2.1: The characteristics and needs of the microbial and mammalian cultures during recombinant protein production.

\begin{tabular}{|c|c|c|c|}
\hline \multicolumn{2}{|c|}{ Microbial cultures } & \multicolumn{2}{|c|}{ Mammalian cultures } \\
\hline Characteristics & Needs & Characteristics & Needs \\
\hline $\begin{array}{l}\text { Inhibiting } \\
\text { metabolite } \\
\text { formation }\end{array}$ & $\begin{array}{l}\text { High dissolved } \\
\text { oxygen and } \\
\text { limited } \\
\text { substrate } \\
\text { concentration in } \\
\text { the media }\end{array}$ & $\begin{array}{l}\text { High sensitivity } \\
\text { to shear-stress }\end{array}$ & $\begin{array}{l}\text { Low stirrer } \\
\text { speed, or } \\
\text { alternative } \\
\text { mixing methods } \\
\text { (e.g. orbital } \\
\text { shaker) }\end{array}$ \\
\hline $\begin{array}{l}\text { High density } \\
\text { cultures }\end{array}$ & $\begin{array}{l}\text { Extensive heat } \\
\text { transfer }\end{array}$ & $\begin{array}{l}\text { Sensitive to } \\
\text { available } \\
\text { oxygen }\end{array}$ & $\begin{array}{l}\text { Easy gas } \\
\text { transfer }\end{array}$ \\
\hline $\begin{array}{l}\text { High oxygen } \\
\text { demand }\end{array}$ & $\begin{array}{l}\text { Efficient oxygen } \\
\text { transfer into the } \\
\text { media }\end{array}$ & $\begin{array}{l}\text { Low product } \\
\text { yield }\end{array}$ & $\begin{array}{l}\text { High reactor } \\
\text { volume }\end{array}$ \\
\hline $\begin{array}{l}\text { High growth } \\
\text { rate }\end{array}$ & $\begin{array}{l}\text { Efficient } \\
\text { aeration and } \\
\text { mixing }\end{array}$ & $\begin{array}{l}\text { Low growth } \\
\text { rate }\end{array}$ & $\begin{array}{l}\text { Long } \\
\text { cultivation time }\end{array}$ \\
\hline & & $\begin{array}{l}\text { High } \\
\text { contamination } \\
\text { risk }\end{array}$ & $\begin{array}{l}\text { Sterile handling, } \\
\text { serum-free } \\
\text { media }\end{array}$ \\
\hline & & $\begin{array}{l}\text { Expensive } \\
\text { media and } \\
\text { product }\end{array}$ & $\begin{array}{l}\text { Minimize } \\
\text { product loss }\end{array}$ \\
\hline
\end{tabular}

Even though some recombinant proteins have been produced in disposable bioreactors by E. coli, the disposable systems are seldom used with microbial cells. The reasons may be connected to the price of the products and the market situation. Still, application of the singleuse reactors has important advantages including the eliminated risk of batch-to-batch product contamination and the decreased production costs through reducing the workload of cleaning, sterilization and validation [29].

The main motivation for using disposable bioreactors for culturing 
mammalian cells is the technically demanding mixing and aeration in large reactors where these cells are cultured due to their lower product titres. The increased stirrer speed and aeration result in higher shearstress which decreases the viability of the cells or even causes cell death. To maintain high viability and meet the oxygen-demand of the cells, the use of disposable solutions where the bioreactor bags are placed on a rocking shaker offers a great advantage.

Furthermore, unlike the stainless-steel reactors, these bioreactor bags are portable, flexible, easy to adapt to various processes and to scaleup/-down. However, their advantages are also hindered by limitations, such as leakage problems due to bag mishandling, the limited capacity of the bags $(2000 \mathrm{~L})$, the lack of product variety and standardization, and the risk of leachables and extractables presence in the media [30]. Although these must be solved in order to be a competitive alternative to stainless-steel reactors, the disposable bioreactors have the potential to become dominantly used in industry.

Measurement technology - both in stainless steel and in disposable bioreactor - must be able cope with the conditions in these reactor systems. The available sensor solutions were developed with a strong focus on the stainless-steel bioreactors and their requirements, neglecting the needs of the single-use bioreactors and delaying their expansion. However, the emerging use of disposable reactor systems calls for innovative ideas in all fields including sensor development, monitoring and control solutions. Consequently, the industry presents an ascending request for measurement technologies adaptable for both bioreactor types which would provide the possibility of multi-use systems. Therefore, the sensors, monitoring techniques and control solution presented in this thesis were designed with a highlight on flexibility and adaptation to both bioreactor systems, fulfilling the above-mentioned aspirations.

\subsection{Current trends, needs and expectations in the bioindustry}

Ten years ago, half of the new recombinant proteins were produced by microorganisms, while today they represent only $13 \%$ of the overall production [25]. The majority of newly approved proteins are mAbs - the most expensive pharmaceuticals on the market - still, the profit 
made on these new drugs is only a few percentages.

Cost reduction is a constant need of the bioindustry. The appearance of new pharmaceutical companies, the emerging market of low-priced generics and biosimilars, and their support by the health authorities are the major driving forces decreasing the prices [31]. Additionally, the new, fast changing market of low-volume production also strengthen the need of transitioning towards scalable, flexible and multi-product lines, due to the emerging popularity of personalized medicine, battlefield medicine and production on demand [32, 33].

Hence, cutting costs is essential, various strategies have been developed to meet this need. One of these solutions is the application of singleuse bioreactors which supports competitiveness by minimizing the investment and manufacturing costs, and by providing flexibility and scalability in production [34].

Another solution for cost reduction is the improvement of product quality and productivity, raising the need of deeper understanding of processes. This can only be achieved by developing and implementing new sensor technologies to monitor important process parameters. Although the processes might have different needs to achieve higher product yield, they all would benefit from monitoring the formation of metabolites with focus on growth inhibiting compounds (acetate, lactate, ethanol). In addition, for mammalian cells producing extracellular products the information on cell viability, productivity and product concentration represent additional value to improve the production. In comparison, for intracellular protein products a deeper insight into the intracellular transformations such as folding could contribute to further reduce the process variability [35].

The work outlined in this thesis mirrors the variety of bioprocesses including both extracellular and intracellular protein production using different cells. Through this diversity of applied production organisms, the varying needs and characteristics of host cells are also addressed. Furthermore, the presented sensors and monitoring techniques contribute to an increased product yield and productivity, and stabilize the product quality. The flexibility and adaptability to different bioreactor systems provided by the described techniques offer a viable alternative to meet the industrial needs. 


\section{Chapter 3}

\section{State-of-the-art of bioprocess monitoring}

\subsection{Process analytical technology as a drive for advancement of bioprocess monitoring}

Process analytical technology (PAT) is described as "a system for designing, analysing, and controlling manufacturing through timely measurements (i.e. during processing) of critical quality and performance attributes of raw and in-process materials and processes, with the goal of ensuring final product quality" [36]. The purpose and novel approach of PAT is to build quality into the product throughout the whole process rather than just testing the quality of the final product [37].

Several measurement techniques can lead to the accomplishment of PAT ambitions. This includes enhancing a better process understanding of the production process, as well as concrete production goals, such as improving the product yield, reducing the process cycle time, achieving a higher energy efficiency of the process and reducing the production costs of the product [38, 39].

To achieve these goals, the bioprocess must be well understood already at the design stage, where the support by efficient measurement techniques, process analysis and control systems are key [38]. During the design phase, when the unit operations of the bioprocess are conceived and configured, their characterization and optimization 
are the most critical steps influencing the process implementation and operation of the final production process.

The first step is the identification and quantification of the critical process parameters (CPPs) and the affected critical quality attributes (CQAs) of the target product. A distinguished attention must be dedicated to those attributes and parameters that can be influenced in each process step.

Once the identification is done, the sensors and techniques capable of monitoring the chosen CPPs and CQAs are determined and selected. During this selection procedure, the most important criteria is the measurement frequency that should be high enough to meet the speed of the process and make real-time process decisions possible.

Finally, based on the data obtained by the selected monitoring techniques a control procedure is developed for the CPPs, allowing consistent process performance and product quality.

Applying PAT to bioprocesses has several additional challenges compare to chemical processes. One reason is that the product is often a large and complex protein with a high variability in the quality which makes it more than just a simple chemical compound. To ensure constant product quality, quality tests of the final product specific to the product biomolecule are required, as well as determining the level of impurities which result in large datasets and complex data processing [40]. This workload can only be minimized through the design of the upstream bioprocess.

Thus, choosing the most appropriate measurement techniques to monitor and control the CPPs and CQAs in USP is of great importance for accomplishing the purpose of PAT, and further discussed in detail in Paper I of this thesis, while Paper II-V present various advancements for providing new tools and methods for reaching the PAT objectives.

\subsection{Monitoring of the bioreactor: standard and advanced methods}

\subsubsection{Consequences of diversity of production systems for monitoring}

The diversity in the cell types used in bioprocesses creates a range of analytical challenges and requirements in finding PAT that can cope 
with the conditions in the cultures.

The CQAs associated with the product are dependent on the CPPs which can be divided into three groups: reactor-, media- and cellrelated CPPs (Figure 3.1). These parameters are highly interconnected: by controlling one of them, a control of others might be also achieved. For example, by controlling the DO level in the reactor, the concentration of inhibiting metabolites, the viability and growth rate of the cells can also be influenced.

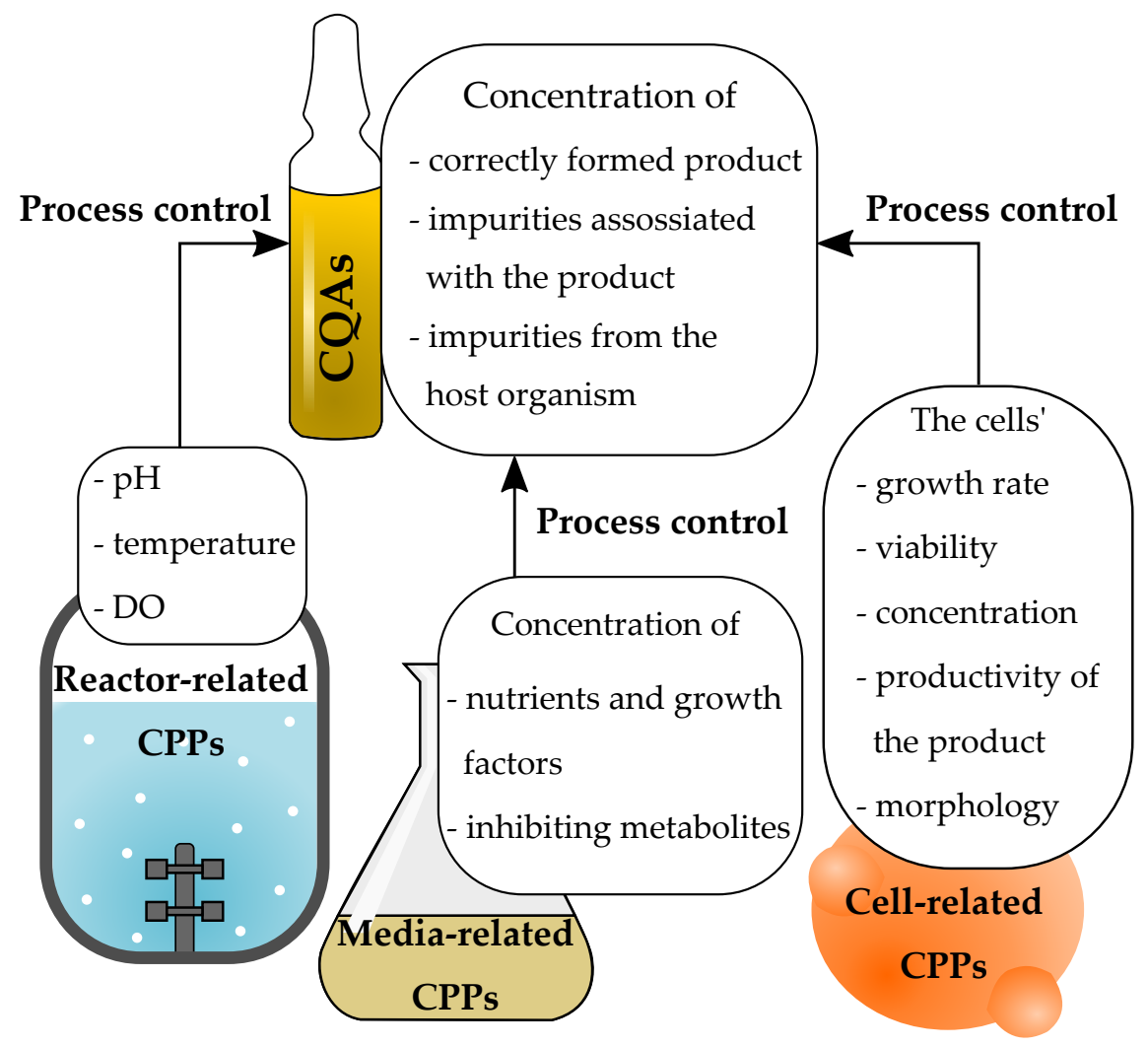

Figure 3.1: The CPPs influencing the CQAs during recombinant protein production and the role of process control as the link between them.

While for the different production organisms the reactor-related CPPs might be the same, other CPPs such as the concentration of inhibiting metabolites, the growth rate, the viability and the productivity of recombinant protein can greatly differ among the host cells. Typically, the concentration range of the inhibiting metabolites and the nutrients 
determines the measurement range and selectivity, and the growth rate of the cells defines the measurement frequency. These differences shape the requirements set for the sensors and must be carefully identified and considered when selecting the applied techniques.

During the monitoring of metabolite and nutrient concentrations, the measurement range of the sensor should cover the lower and upper concentration limits reached during the process and the selected method must be selective to the molecule in question. Reaching these goals can be challenging when the target molecule is present in the media composition and increases the background noise, and when other media compounds interfere with the measurement signal.

The minimum measurement frequency of the sensor - the time required to obtain data from the process - must be at least in the same order of magnitude as the doubling time of the cells, preferably even shorter. In the processes with mammalian cells this should be in the range of 24-48 hours, with yeast cells within 100-200 minutes, and with E. coli and other bacteria as short as 20 minutes.

This frequency might be further increased based on the importance of the CQAs since the higher the frequency of the measurement, the better the monitoring and the control effects. But even though some of the CPPs are considered very important (e.g. productivity), the desired measurement frequency may not match the time needed for obtaining the results. For example, the proteins expressed extracellularly can be measured as often as every 20 minutes with high-performance liquid chromatography (HPLC), while for the intracellular proteins, only the renaturation of the protein can take several hours [41, 42].

This thesis contributes to the improved monitoring of both media- and cell-related CPPs. In Paper V, a single-use biosensor was designed to monitor lactate concentration in the media as one the important CPPs in mammalian cell culture processes. This measurement technology has the potential to be applied with other analytical enzymes than lactate oxidase to monitor multitude of CPPs present in culture media. In comparison, the morphology as a cell-related CPP influencing both cell growth and production was identified with the evaluation of capacitance spectra in insulin or green-fluorescent protein (GFP) producing bacteria in Paper II. The methodology showed the potential to be applied with other hosts such as yeast as it is discussed in Paper IV. As primary CPPs, biomass concentration and growth rate have been controlled through the supply of nutrients in a recombinant bacterial culture presented in Paper III. 


\subsubsection{Standard and advanced monitoring}

Bioprocess monitoring techniques can also be considered through the way the analytical data of the culture is analysed. The sampling can be carried out (1) off-line where the sample is removed from the culture and analysed at another laboratory away from process line, (2) at-line where the sample is still removed from the culture but analysed close to the process line, and (3) in-line/in-situ where no sample removal occurs and the analysis is carried out directly in the bioreactor (Figure 3.2).

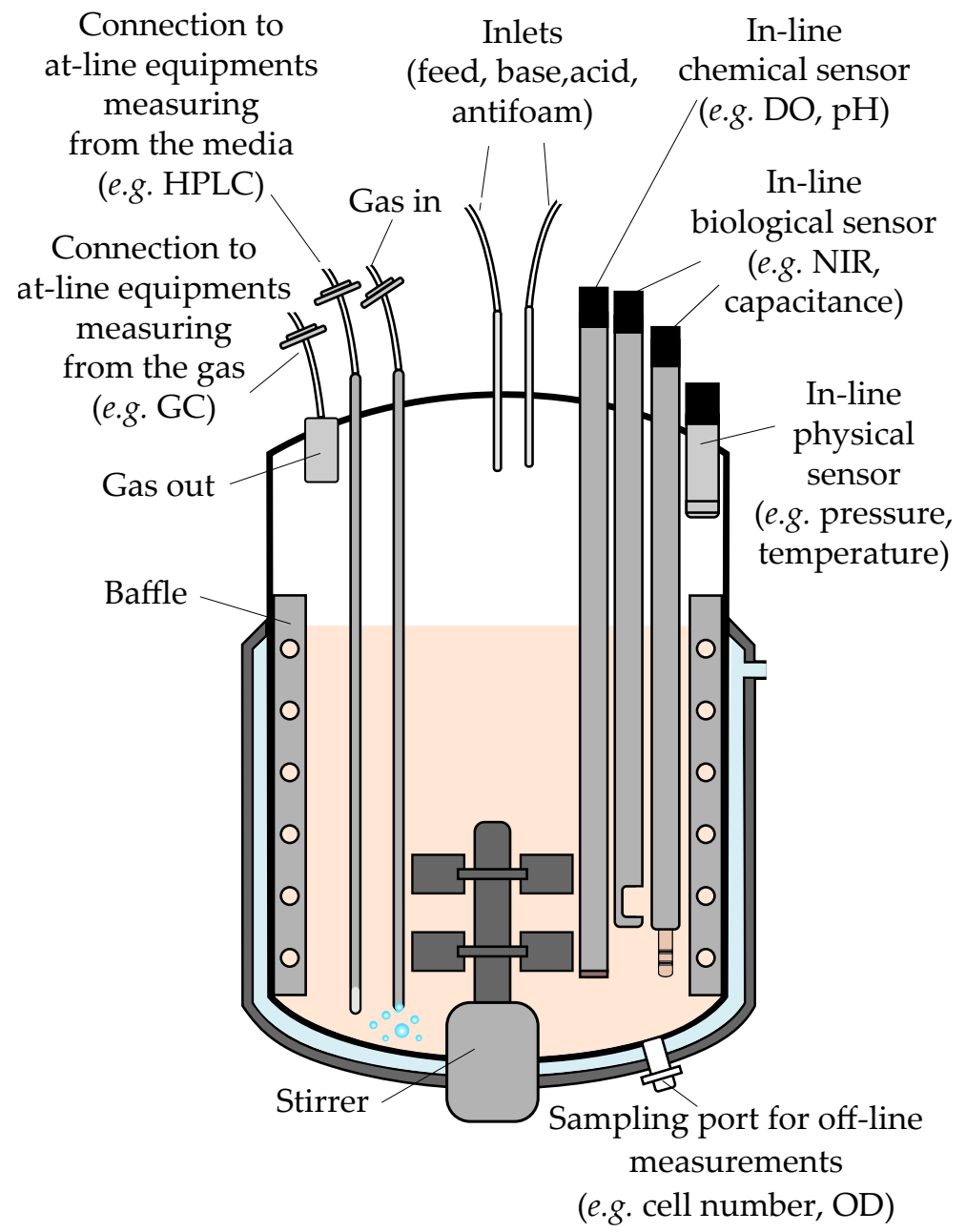

Figure 3.2: The standard bioreactor setup showing the in-line, at-line and off-line measurement possibilities and their integration with the bioreactor. 
The need for acquiring the data close to real-time often makes insitu monitoring techniques the preferred method, as they allow high measurement frequency and the risk of contaminating the bioreactor culture is minimized.

The variables measured by various monitoring methods can be categorised into:

- physical variables describing the physical state of the bioreactor (agitation rate, temperature, pressure) and the culture in it (viscosity, shear stress, weight),

- chemical variables connected to all chemical compounds in the bioreactor culture (nutrients, excreted metabolites, gases) including the target product and its variants,

- and biological variables directly related to the cells (growth rate, cell distribution, division time, morphology) [43].

In standard bioreactor monitoring, all the physical variables such as temperature, pressure and resistance (foam formation) are measured real-time and in-situ. These are commonly supported by in-line/in-situ sensors tracking chemical parameters critical for the survival of the culture such as dissolved oxygen (DO), $\mathrm{pH}$ and the respiratory quotient $\left(\mathrm{CO}_{2} / \mathrm{O}_{2}\right.$ concentration) (Figure 3.2).

To understand the behaviour of the bioreactor culture, other chemical parameters need to be monitored, such as media components and composition, metabolites from the cells, the concentrations of the product and its variants. Suitable analytical techniques for this could be HPLC, gas chromatography (GC), spectroscopic methods (nearinfrared (NIR), fluorescence and Raman) and different biosensors [44-46]. By gaining a deeper insight into the metabolic state of the cells and the changes of the media composition, additional CPPs might be identified which can further facilitate the control of the CQAs at the target values.

Advancement in monitoring and measurement techniques to meet the requirements mentioned above are of great importance. This especially concerns better techniques for monitoring of the biological variables, including more accurate determination of biomass concentration at different media background, cell morphology and internal metabolism. To achieve this, optical sensors (NIR, fluorescence), capacitance sensors or in-situ microscopic techniques are potential alternatives [47, 48]. 
These sensors have the capacity to refine the information from the standard reactor monitoring methods and thereby extend the existing knowledge when being combined with data on chemical variables.

When implementing new monitoring tools and devices in bioreactor systems, the users' needs and the requirements of the production process must be carefully mapped. It is then very important to accurately define the analytical performance of the new tool (e.g. sensitivity, transferability, robustness and stability) required in the bioprocess. This includes ensuring that there are good possibilities to carry out accurate sensor calibration, determining if the monitoring technique shall measure continuously or if a single-use tool is sufficient, and calculating its purchase and maintenance cost [49].

By implementing an additional well-selected sensor tool to the bioreactor monitoring system, the total costs of the bioprocess may be considerably reduced. Moreover, it can contribute to a decreased batch-to-batch variability and minimized loss of product yield, to an increased productivity of both cells and products, and to a stabilized quality of the final product.

In this thesis, the above mentioned requirements are highlighted in several ways. The users' needs, the requirements set for both the monitoring techniques and the available sensor setups are described in Paper I. This is taken one step further by identifying analytical performance of a lactate biosensor in Paper $\mathrm{V}$ and advancing the capacitance sensor to a multipurpose sensor by the identification of morphological changes in bacteria and yeast as presented in Paper II and IV. The work outlined in Paper III not only determines the upcoming challenges during sensor implementation, but it also presents a setup capable of controlling recombinant protein production in bacteria. 



\section{Chapter 4}

\section{Implementing monitoring methods for bioprocess control}

\subsection{Adaptation of monitoring techniques to improve control}

After selecting the sensor techniques most suitable for measuring the CPPs identified during the design phase, monitoring of the bioprocess can be realised and their signal can be used as input for process control. This is one of the primary ambitions of PAT and an important prerequisite for being able to achieve efficient control by linking the CPPs to the quality as defined by the CQAs.

Sensors placed in situ in the process are the best suited to successfully apply feedback control, both due to their continuous operation and the real-time delivery of signals. However, techniques measuring atline near the process can also serve with efficiency in control, if the measured variables are delivered fast enough to allow control actions in due time in relation to the dynamics of the process. In case the measurements are too slow compared to the changes in the process, the measured information can still be used to retrospectively confirm control effects. For the same reason, off-line sensors can only be applied to support process decisions or to gain further insights into the system. 
However, there are a few additional requirements that the monitoring technique must fulfil to allow implementation into a control system. First, the performance of the sensors shall not be affected by the harsh sterilization conditions (high temperature and pressure) resulting in deteriorating analytical performance. Furthermore, there should be no baseline drift of the monitored signal that makes recalibration necessary during the process and thereby interrupts the control procedure. Finally, the measurements must provide a stable and continuous signal, easily accessible through the software used for data transfer to the controller system.

\subsection{Control methods in bio-industrial practice}

\subsubsection{Feed-forward and feedback control in fed-batch processes}

In process control, there are three important variables: the controlled, the measured and the manipulated variable. The controlled variable is the parameter controlled in the process; the measured variable is an electronic representation of the controlled variable (e.g. a sensor signal) while the manipulated variable is the adjusted parameter that keeps the controlled variable at the setpoint value. In fed-batch bioprocesses, the manipulated variable is most commonly the feed rate of the nutrient media.

Feed-forward control operates based on controlled and manipulated variables only, thus it does not require any sensor inputs (Figure 4.1). Instead, it works based on a model built from empirical knowledge of the system. In fed-batch bioprocesses this is realised by using a predefined feeding scheme (derived from the initial conditions of the biomass concentration) where the feed rate is set either to constant, increased or exponential profile.

The shape of the feeding profile has a direct effect on the cells' growth rate, allowing its control at different levels. During the fed-batch process, the growth rate continuously decreases if a constant feed profile is used. But by applying either an increased (gradually, stepwise or linearly increased) or an exponential feed, this decrease can be eliminated and the growth rate becomes constant [50].

Although the feed-forward systems are unable to compensate for process disturbances because the output of the control system is not 
measured, some industrial cultivation processes are still operated with them due to their simplicity of implementation and minimal cost [5153].

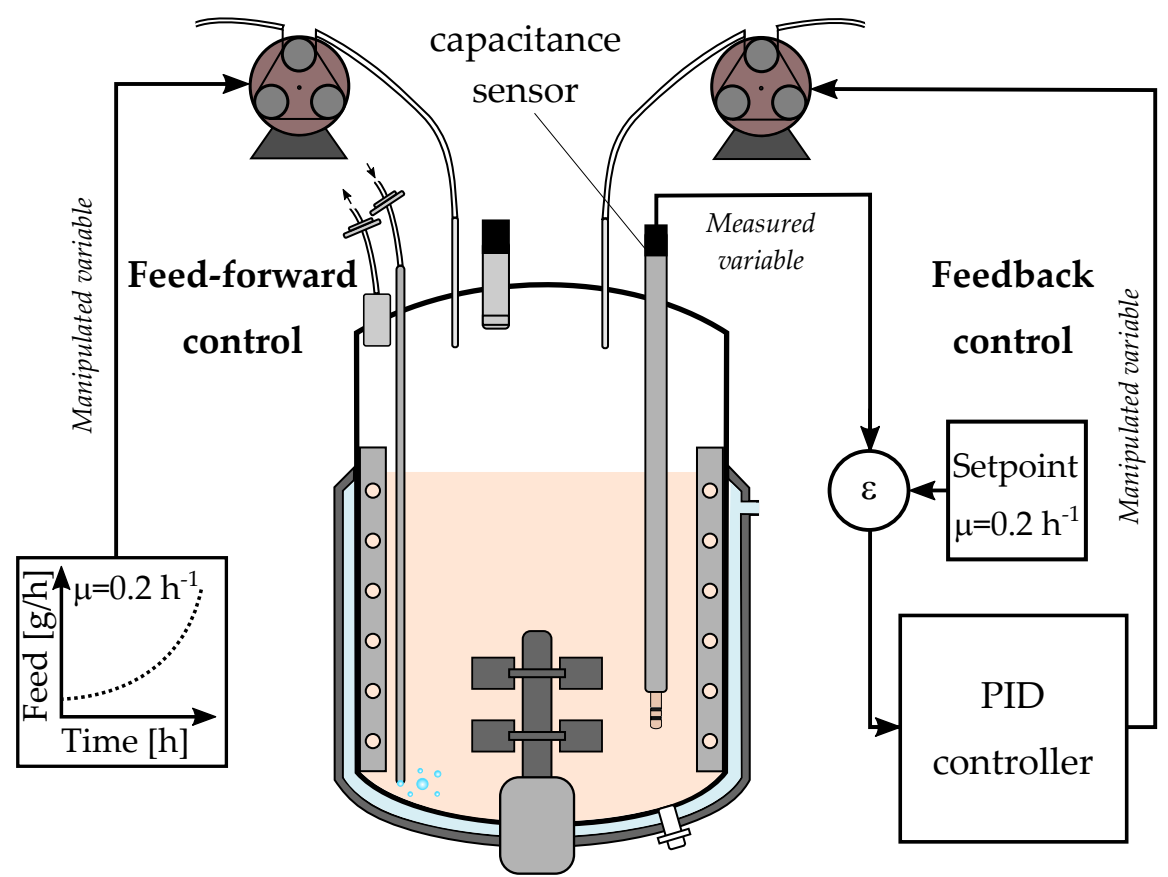

Figure 4.1: Control in a fed-batch process: the growth rate $(\mu)$ is controlled by a feed-forward controller following a pre-defined feeding scheme and by a feedback PID controller at a setpoint of $0.2 \mathrm{~h}^{-1}$ with the help of a capacitance sensor.

In feedback control, the output signal is compared with the setpoint of the controlled variable and the difference between these, the control error $(\varepsilon)$, is calculated (Figure 4.1). This error is then used to adjust the manipulated variable in order to bring the controlled variable back to its setpoint. This allows the system to adapt to internal or external disturbances during the process.

Based on how the information on the controlled variable is provided, two different control approaches can be implemented: indirect or direct. The indirect feedback control adds feeding solution to the reactor in relation to the deviation of measured indirect parameters from the setpoint (e.g. DO, $\mathrm{pH}$, carbon-dioxide evolution rate (CER), cell or metabolite concentration) [54-57]. The direct feedback control however, 
adjusts the feed rate based on the nutrient concentration (e.g. glucose or lactose) measured directly in the bioreactor [58].

The measured variables of the feedback control can also be distinguished into direct and indirect variables [59]. The directly measured variables are monitored by an in situ or in-line sensor (temperature, DO and $\mathrm{pH}$ probe, spectrophotometers, HPLC, GC, substrate and metabolite analysers). The indirectly measured variables (specific growth rate, biomass concentration, oxygen uptake rate/transfer rate and CER) are estimated from directly measured variables. Such procedures, where an algorithm or model is used in the estimation are often referred to as software sensors (or soft sensors). Today's rapid advancements in process computer technology make soft sensor-like approaches more frequently applied as process monitoring and control tools, also in bioprocessing but with some reluctance [60].

\subsubsection{Feedback control solutions}

Several feedback control systems are applied in control engineering, from simple on/off to complex estimator-based controllers.

One of the most commonly applied controllers in industry is the PIDcontroller in which the control response action is the weighted sum of three terms: a proportional, an integral and a derivative term [61]. The proportional term $(\mathrm{P})$ is a linear correlation between the error and the manipulated/controlled variable, while the integral term (I) is responsible for eliminating the steady-state error caused by the P term and for the delay in the response of the control action. The derivative term (D) predicts the direction of the controlled variable by projecting the current rate of change within a defined forthcoming time period (Figure 4.2). The P, I and D terms are used in various combinations (PI, PD, PID or only P) in order to obtain the best controller performance. In bioreactors, the most popular combination is the PI controller, but sometimes PID controllers are also used for controlling the essential control loops (reactor airflow, $\mathrm{pH}$, temperature, pressure, dissolved oxygen, cooling water, stirrer speed) [62]. 
a)

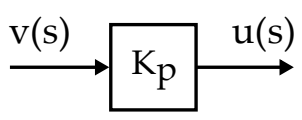

b)

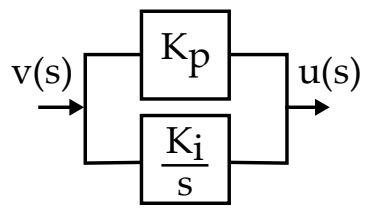

c)

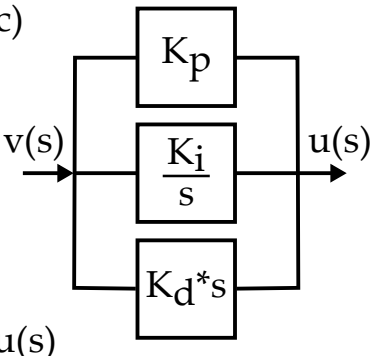

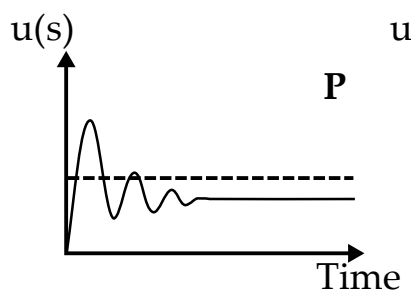

$\mathrm{u}(\mathrm{s})$
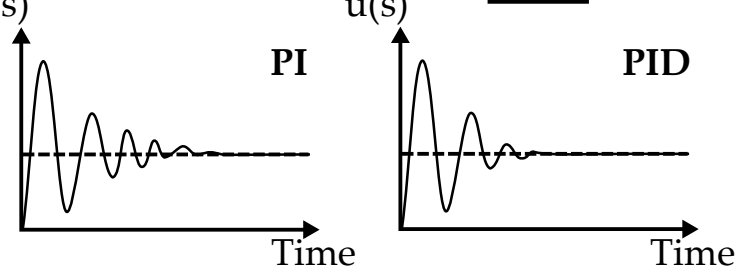

Figure 4.2: The changes in the output signal (u) using a (a) P, (b) PI and (c) PID controller.

As the PID-controllers are best suited for linearly behaving processes, they are not the best solution for controlling the non-linear behaviour of bioprocesses. The non-linearity can appear due to the growth on a limiting substrate or due to the shifts occurring in the metabolism under certain culture conditions. These cases may seriously compromise the performance of the cultivation process, making it difficult for the controller to carry out a perfect control.

By using other control solutions, such as gain-scheduling, modelbased and adaptive control, significantly better performance may be achieved than by PID-controllers [63]. Gain-scheduling provides a straightforward solution for anticipating non-linear process behaviours; however, it requires a good understanding of process behaviour and must also be based on well-tuned controller parameters for each growth phase in a transient cultivation process. Model-based controller are specially designed to deal with highly complex processes such as cultivations. These controllers are well-suited to handle delays in both the sensor signals and the responses of the system by predicting the response of the process (model predictive control) and leading the control action along a trajectory. Adaptive controllers can manage all other uncertainties that may occur during cultivations but are hard to model, such as gradients and extended response times of sensors. This is accomplished by using a parameter adaptation algorithm in the controller that dynamically adapt the parameters of a linear process 
model, based on the error between the measured and predicted state variable.

Compared to other industrial sectors, the bioprocess industry shows reluctance in applying advanced control technology. This can partly be explained by the requirements on process validation, the lack of evidence of improved productivity and the preference for simplicity in operation [62].

The control approach that has been applied in this thesis is a combination of a feed-forward and feedback controller, merging the advantages of both systems. The feed-forward system provided the non-linear trajectory while the feedback PI-controller coped with the disturbances of the system and ensured that the culture is kept at the right growth rate.

\subsection{Validation of bioprocesses}

The bioprocess industry producing drugs and food has high regulatory demands on process validation including process control methods and their performance. Before a commercial drug manufacture begins, a mandatory validation of the entire process must be completed according to the established process validation procedures and guidelines, such as the Continued Process Verification (CPV) guidance specified by the International Council for Harmonisation of Technical Requirements for Pharmaceuticals for Human Use (ICH) [64].

$\mathrm{CPV}$ is a validation procedure that spans over the lifetime of the production plant and includes product stability data, change control and annual product reviews along with statistical process control (SPC) techniques to ensure that the process remains within the validated state.

After the validation procedure is completed, SPC are used to ensure consistent production of the product according to the quality criteria approved by the authorities. When applying SPC, the key quality parameters are often visualised in control time charts showing the expected range of values for process or quality related variables with their upper and lower control limits, warning limits and specification limit. These limits are identified, and set based on historical performance of the process. Through this procedure, the causes of variation are identified and continuously attempted to be reduced, resulting in better process stability and future performance. 
When a new monitoring or control system is implemented into an already existing manufacturing process, the validation must be performed again for the entire process. Therefore, sensors and other measurement techniques that easily can be adapted to diverse process conditions or able to measure multiple analytes should be prioritized during the design of a monitoring and control system.

These needs were considered when designing the control system concept in Paper III, where a combined feed-forward/feedback controller system was used to indirectly control the specific growth rate of the cells. The feed-forward exponential feeding system provided the trajectory of the desired feed rate while the feedback control loop compensated the changes occurring in the process. The system in Paper III demonstrates an easily-adaptable, low cost and user-friendly upgrade to the already existing systems commonly used in industry which, after initial adaptations, could be used with other sensor alternatives such as the capacitance sensor. 



\section{Chapter 5}

\section{From single-use to in-line: monitoring methods}

exploited in this thesis in

\section{theory and practice}

\subsection{Rapid, low-cost monitoring of key metabolites to provide CPP data just-in-time}

The concentration of different metabolites such as lactate, acetate and ethanol represents an important group of CPPs affecting a wide variety of cell-related CPPs such as the cell's growth rate, metabolic state, and by that the CQAs, including the quality and quantity of the product of interest. Consequently, their monitoring and control can ensure to keep the key attributes at the desired states.

Screen-printed biosensor designs provide an interesting possibility to measure media-related CPPs. They have unique advantages, such as easy mass production, suitable miniaturisation and low cost [65]. During screen-printing, the key components of the sensor, i.e. the working/reference electrodes and connecting pads, are printed in liquid form on the surface of a foil and fixed by a curing method (e.g. thermal curing).

In enzyme biosensors, the enzyme placed in close proximity to the 
working electrode surface catalyses the electrochemical reaction. The commonly used enzymes for L-lactate determination are L-lactate oxidase (LOD) or dehydrogenase enzymes (LDH), while lactate monooxidase and cytochrome b2 can also be used but are seldom applied.

In Paper V, LOD was used to fabricate a single-use screen-printed biosensor for monitoring L-lactate concentration during bioprocesses where lactate plays a crucial role (e.g. mammalian cell cultures, lactic acid fermentations). The design concept was a two-electrode amperometric system with a carbon working electrode and a $\mathrm{Ag} / \mathrm{AgCl}$ reference electrode printed on a polyethylene terephthalate (PET) foil (Figure 5.1a).

a)

\section{Carbon working electrode}

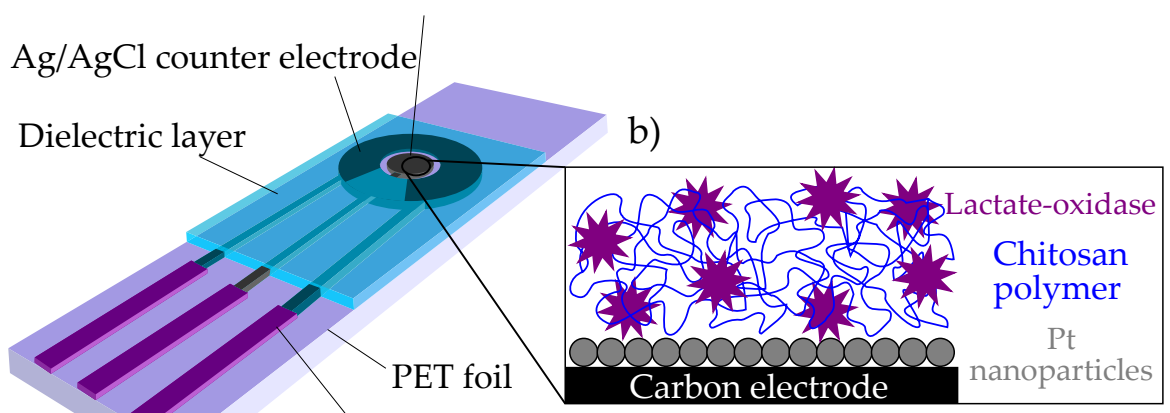

Silver connector

Figure 5.1: (a) The structure of the screen-printed L-lactate biosensor with a zoom-in on (b) the working electrode's surface demonstrating the immobilization of the lactate oxidase enzyme.

In amperometric biosensors, the current of the working electrode is recorded during oxidation or reduction, and this response is directly proportional to the analyte concentration in the sample [66]. The oxidation/reduction reaction in the L-lactate biosensor used in Paper $\mathrm{V}$ is governed by the following three equations:

$$
\begin{aligned}
L-\text { lactate } \mathrm{FAD}_{(L O D)} & \rightarrow \text { Pyruvate }+\mathrm{FADH}_{2(L O D)} \\
\mathrm{FADH}_{2(L O D)}+\mathrm{O}_{2} & \rightarrow \mathrm{H}_{2} \mathrm{O}_{2}+F A D_{(L O D)} \\
\mathrm{H}_{2} \mathrm{O}_{2} & \rightarrow 2 \mathrm{H}^{+}+\mathrm{O}_{2}+2 e^{-}
\end{aligned}
$$


where the electrons are transferred by the flavin adenine dinucleotide (FAD) cofactor bound to the enzyme and responsible for producing the electric current.

Thus, the enzyme itself is the most critical component in enzyme-based biosensors. It provides the selectivity of the sensor and catalyses the electroactive compound formation, it determines the shelf life, the stability and the lifespan of the biosensor. Subsequently, obtaining the optimum stability, the selectivity, the activity and the reaction efficiencies of the enzyme is crucial during the enzyme immobilization onto the sensor surface. Several strategies exist to immobilize enzymes onto the electrode surface, such as cross-linking, covalent bounding, entrapping in conductive/nonconductive polymers or in a sol-gel or hydrogel matrix, and immobilizing with another biological component (e.g. bovine serum albumin) $[67,68]$.

Immobilizing the L-lactate oxidase in a chitosan membrane, as applied in Paper V, has several advantages (Figure 5.1b). Chitosan is non-toxic, biocompatible with proteins, and ensures that the enzyme can sustain its right conformation and activity. While the membrane serves as a barrier for interferences and protects the enzyme structures against fouling, it also leads to an extension of the linear response of the biosensor [67].

Due to the immobilization in the membrane, the distance between the enzyme molecules and the surface of the working electrode increases which obstructs the transport of the electrons to the surface. To compensate for this effect, the electrode surface area should be extended to facilitate the transport and boost the sensitivity. This can be done by applying different nanomaterials, such as carbon nanotubes, gold or platinum nanoparticles, nanoparticles of metal oxides (e.g. niobium or molybdenum oxide) and semiconducting materials (e.g. zinc oxide) (Figure 5.1b). In Paper V, this was achieved by the deposition of platinum nanoparticles onto the surface of the carbon electrode.

After characterization and calibration in the different culture media, the biosensor was used to monitor lactate in a Corynebacterium glutamicum and two $\mathrm{CHO}$ cell cultivations. Although in situ monitoring techniques are preferred when monitoring CPPs, in some cases, e.g. cells with small growth rate (such as $\mathrm{CHO}$ cells), at-line techniques that can provide additional information on the state of the cells such as singleuse sensors are also of great interest. These sensors are an alternative to in situ sensors because they still can measure within a few minutes. In 
addition, their need of sample volume is just a few microliters, which is important when the product is expensive or produced in small volume as common with for example mAbs.

The design of the biosensor in Paper $\mathrm{V}$ was successfully applied to monitor the variations of the lactate concentration in a wide range (5-30 $\mathrm{mM})$, comparable with the standard monitoring methods such as HPLC and colorimetric enzymatic kit (Figure 5.2). Although, the biosensor demonstrated difficulties to accurately measure below $5 \mathrm{mM}$, this was not considered as a major drawback because the relevant concentration range in upstream bioprocesses is generally above this level [69].

a)

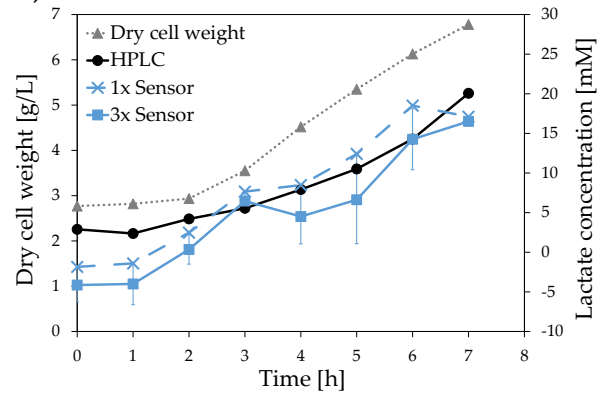

b)

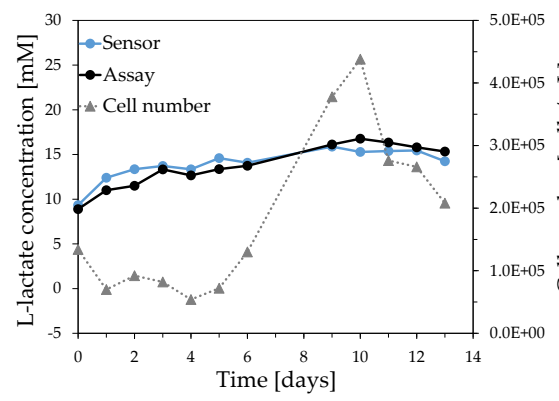

c)

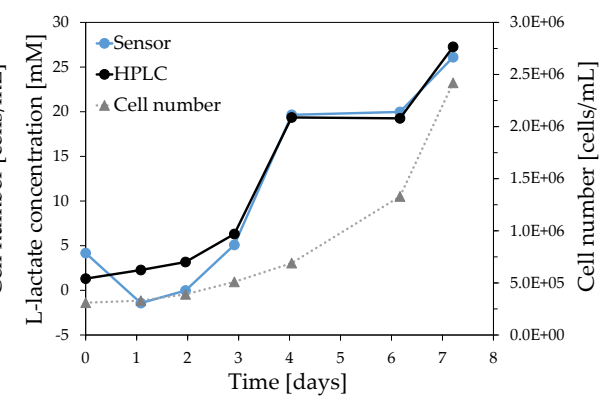

Figure 5.2: The measured L-lactate concentrations by the screen-printed biosensor in three different media, compared with standard monitoring methods (HPLC, colorimetric enzyme kit) during (a) Corynebacterium glutamicum, (b) $\mathrm{CHO}$ batch and (c) $\mathrm{CHO}$ fed-batch cultivations. [70]

During the experimental evaluation of the sensor's performance, needs for further improvements were identified, such as prolonging the operational stability of the enzyme, using portable dispensing tools for 
5.2. Extracting additional information on morphological state of the cells by combining monitoring methods

enzyme deposition and improving storage stability of the single-use units, e.g. in aluminium packages with a better controlled environment.

\subsection{Extracting additional information on morphological state of the cells by combining monitoring methods}

Cells are the core of the production system in bioprocesses: their fitness, activity, growth and state have a direct effect on the productivity and the quality of the product. Thus, these cell-related CPPs are often considered very important in recombinant protein production, as well as other bioprocesses where the product is a result of biochemical or biological conversions. Consequently, any information regarding the additional parameters that may influence the process productivity and quality can be of value.

Morphology is one such example. It not only provides information on the state of the culture, but it also indicates if the cells are under cellular stress which can lead to severe consequences including process stability and product quality. Morphology may also be linked to these critical issues through abnormal or blocked cell division, decreased cell number, growth rate and thus, productivity which all must be prevented [13, 15].

Today, a variety of monitoring techniques are available for identifying the morphological changes in cells, such as coulter counter, flow cytometry and different microscopy techniques [71, 72]. These are valuable techniques but are impeded by many complications when it comes to in situ monitoring of the morphology of the cells. For example, the coulter counter only gives information regarding cell size; the flow-cytometry requires sample preparation (e.g. labelling); the microscopic techniques are either off-line methods with extensive sample preparation or in situ which are still in the beginning of their development when it comes to identification of morphological changes. Besides, these techniques have high investment and/or maintenance costs and are often coupled with long delays before analytical data can be delivered, especially compared to the growth rate of the cells.

Capacitance sensor has been successfully used to monitor viable cell concentration since 30 years [73-75]. Its measurement principle relies on the fact that cells that have an intact, electrically insulating 
membrane act as capacitors when applying an alternating voltage while dead cells, cell debris and other components (air bubbles, solid media components) do not display the same behaviour (Figure 5.3) [76].

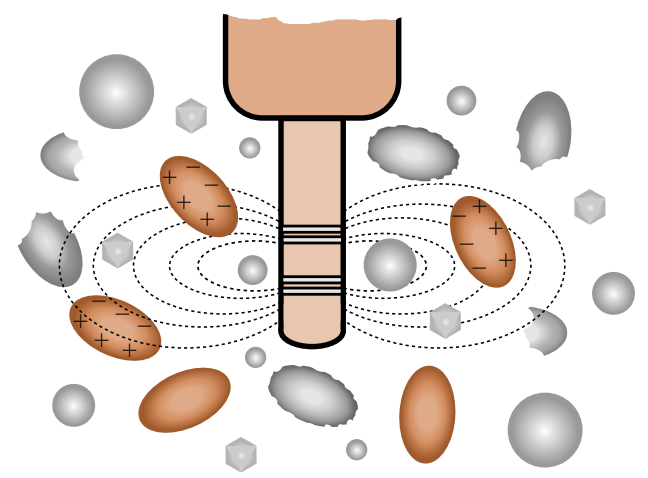

Figure 5.3: The measurement principle of the capacitance sensor showing the measured live cells in colour while all non-disturbing components (dead cells, cell debris, media particles, air bubbles) in grey.

The capacitance spectra is obtained by recording the capacitance while scanning through the available frequency range. During the scan, the cell membrane's conductivity shifts from non-conductive to highly conductive [77] which results in characteristic plateaus in the capacitance spectra for spherical cells.

$$
C(f)=\frac{\Delta C \cdot\left(1+\left(\frac{f}{f_{c}}\right)^{(1-\alpha)} \sin \left(\frac{\pi}{2} \alpha\right)\right)}{\left(1+\left(\frac{f}{f_{c}}\right)^{(2-2 \alpha)}+2\left(\frac{f}{f_{c}}\right)^{(1-\alpha)} \sin \left(\frac{\pi}{2} \alpha\right)\right)}+C_{\infty}
$$

By fitting the Cole-Cole equation (5.4) to the experimental capacitance spectra, three characteristic parameters can be determined [78]. The capacitance increment $(\Delta C)$ which is determined theoretically at the low frequency plateau, the critical frequency $\left(f_{c}\right)$ which is the frequency where the increment reaches its half and the Cole-Cole alfa $(\alpha)$ which describes the steepness of the curve (Figure 5.4a). 
a)

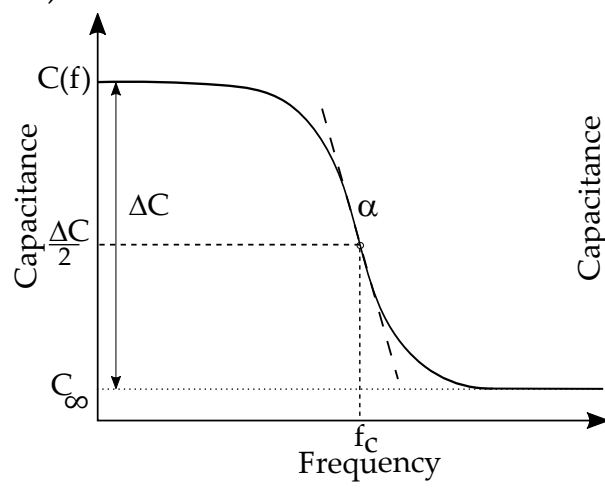

b)

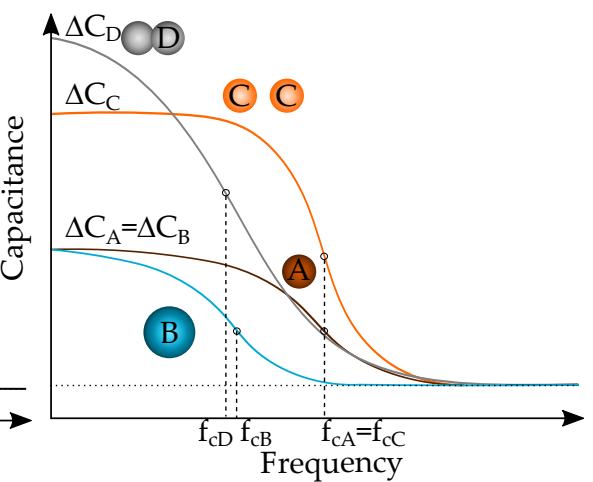

Figure 5.4: (a) The shape of a capacitance spectra with its three major characteristics: the capacitance increment $(\Delta C)$, the critical frequency $\left(f_{c}\right)$ and the Cole-Cole alpha $(\alpha)$. (b) The development of the capacitance spectra and its major characteristics for a spherical cell (A), after its growth in cell diameter (B), during (D) and after its division (C).

The cell-related parameters, such as volume fraction $(P)$ and mean cell radius $(r)$, are calculated by using the three major characteristics of the scan together with the measured conductivities in the external medium surrounding the cell $\left(\sigma_{0}{ }^{\prime}\right)$ and the cytosol inside the cell $\left(\sigma_{i}{ }^{\prime}\right)$ [79]:

$$
\begin{gathered}
\Delta C=\frac{9}{4} P \cdot r \cdot C_{m} \\
f_{c}=\frac{1}{2} \pi \cdot r \cdot C_{m}\left(\frac{1}{\sigma_{i}^{\prime}}+\frac{1}{2 \sigma_{0}^{\prime}}\right)
\end{gathered}
$$

It is important that for (Eq. 5.5) and (Eq. 5.6) to be valid, the cells are theoretically assumed to be spherically shaped with a constant radius $(r)$, and surrounded by a single, poorly conducting cell wall or membrane with a fixed membrane potential $\left(C_{m}\right)$ [80]. When these conditions are fulfilled, the volume fraction (the volume of cells in the cell suspension) is linear with the viable cell concentration and cell weight.

And while the assumptions about the cell membrane proved to be accurate, even the spherical cells modify their size and shape during the cultivation time which then may cause deviation from the plateau shape in certain cases (Figure 5.4b). However, cells with 
different shapes than spherical (e.g. straight/spiral/spore forming rods, filaments, aggregates, clusters) cannot be estimated by these equations accurately. Thus, it is essential to investigate what possibilities there are to extend the model described above to include shapes other than sphere. By doing this, the influence by both shape and size changes could be taken into consideration when analysing the capacitance spectrum, and it would ensure that more accurate measurements are performed, as also suggested by others [81-83].

Several models exist to describe the morphological changes of the cells. The morphological effects of the spherical cell division and the increasing length-to-diameter ratio of prolate spheroids (describing rod shape) were both modelled previously $[84,85]$. The results of these models suggest that an increase of the length-to-diameter ratio not only causes increase in the capacitance at low frequency (generally where $\Delta C$ is measured), but also shifts the critical frequency to lower values. The first step towards a better model for describing the non-spherical cells is to map the influence of various morphological forms on the capacitance spectra by experiments. This requires a series of experimental cultivation runs to test the effect of various morphological forms on the manually acquired capacitance spectra, and to check how the sensor's automatic frequency scan measurements correlate with the cells' morphological changes.

In Paper II and IV, the capacitance spectra from the sensor were recorded in two different ways after the morphological changes appeared in the cultures: by manual acquisition from the sensor software (for cultivations with two E. coli strains), and by automatic acquisition using the software's frequency scanning mode (for a $S$. cerevisiae strain).

In Paper II, the two E. coli strains expressed recombinant proteins after induction: one strain produced GFP and the other strain insulin. Uninduced cells of both strains not producing any recombinant protein served as reference cultivations. The scanning electron microscope (SEM) images taken of the cultures (Figure 5.5) were compared with the manually measured capacitance spectra and the DCW of the cells. 
5.2. Extracting additional information on morphological state of the cells by combining monitoring methods

a)

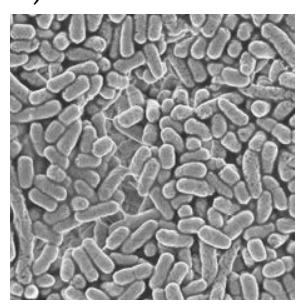

e)

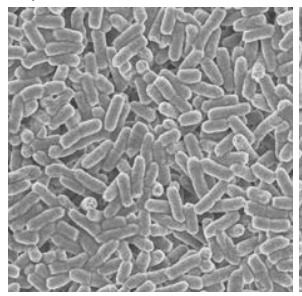

b)

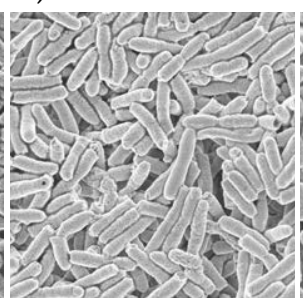

f)

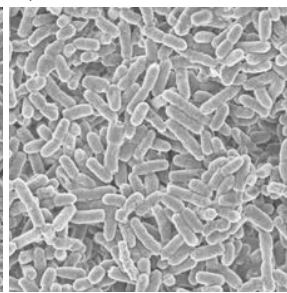

c)

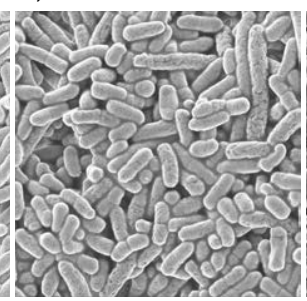

g)

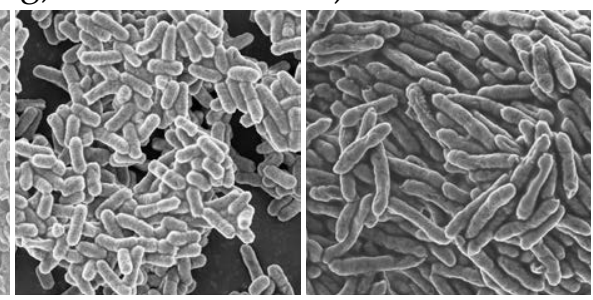

d)

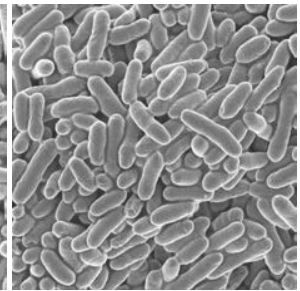

h)

Figure 5.5: The SEM images showing the morphological changes in the four different cultivations: (a-b) uninduced GFP, (c-d) induced GFP, (e-f) uninduced insulin and $(\mathrm{g}-\mathrm{h})$ induced insulin cultures. The first picture of each pair is taken at the start of the fed-batch while the second at the end of the feed.

As seen on Figure 5.6a, the capacitance spectra of the two strains looked very different at the end of the fed-batch: the GFP-producing cells kept their plateau-like shape, both for induced and uninduced cultures, with a rise in $\Delta C$; while the insulin-expressing cells only had this shape when they did not produce insulin. When the insulin production was induced in these cells, the shape of the capacitance spectra developed to an almost linear curve.

After the spectra were compared with the measured DCW and cell size, the only possible explanation for this phenomenon was the significantly increased size of the cells after the induction of recombinant protein expression, which was not observed in the other cultures (Figure 5.6b). 
a)

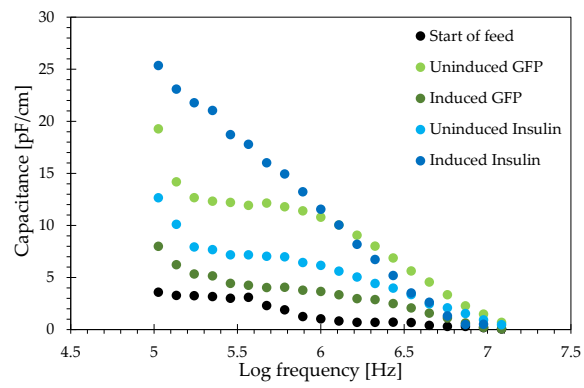

b)

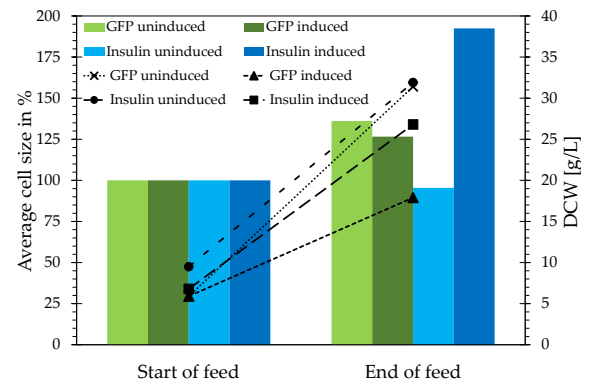

Figure 5.6: (a) The manually measured capacitance of the cultures at the start and at the endof the feed. (b) The average size the cells (columns) compared to the initial size at the start of the feed, together with their DCW (datapoints) at the start and at the end of the feed. [86]

In Paper IV, the coulter counter and DCW measurements were compared with the results of the automatic frequency scan measurements of the capacitance the sensor to evaluate the effect of the morphological differences in yeast cell cultivations. The morphological changes were induced by the addition of isopropyl-alcohol (IPA).

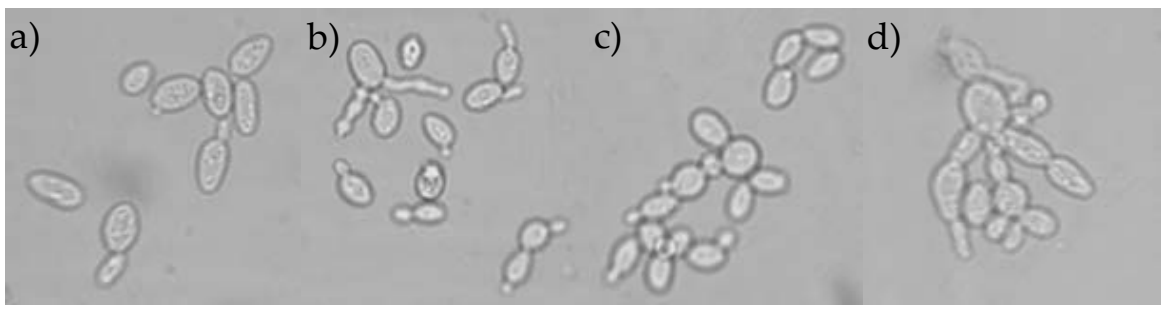

Figure 5.7: The different morphological appearances of the yeast cells: (a) normal and (b-d) abnormal. (Rearranged from Paper IV.)

As an effect of IPA, the induced yeast cells had a higher ratio of abnormal morphologies present in the culture. This was in contrast with the uninduced cells where the cells with normal morphology dominated and only few abnormal cells were present (Figure 5.7). The effect of the abnormal morphological cells was not recognisable from the examination of the characteristics in the mean and mode cell size (Figure 5.8). The only difference visible in these measurements were due to the varying growth rate between the cultivations: cells growing at $0.2 \mathrm{~h}^{-1}$ specific growth rate had higher mean and mode cell size than the cells growing at higher $\left(0.3 \mathrm{~h}^{-1}\right)$ or lower $\left(0.1 \mathrm{~h}^{-1}\right)$ growth rates. 
5.2. Extracting additional information on morphological state of the cells by combining monitoring methods

a)

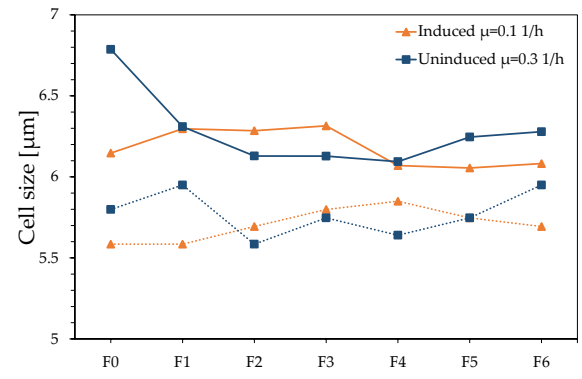

b)

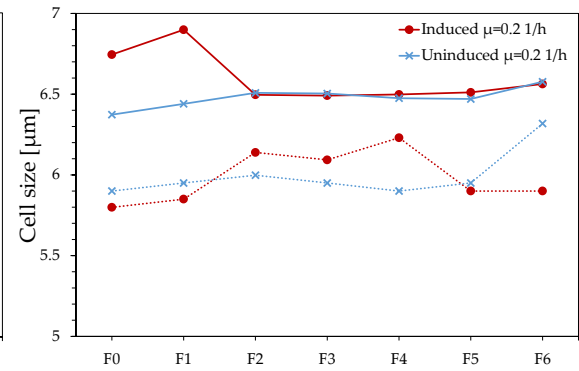

Figure 5.8: The transitions in the mean (solid lines) and the mode (dotted lines) cell size of the cells during the four cultivations. (Redrawn from Paper IV.)

Similarly, the differences in the size distribution of the cells were only visible between the cultures with different growth rates (see Figure 5 in Paper IV): the highest ratio of bigger cells $(>5 \mu \mathrm{m})$ were observed at $0.2 \mathrm{~h}^{-1}$ growth rate while at other growth rates cells buds $(<5 \mu \mathrm{m})$ and single/budding cells $(5-6 \mu \mathrm{m})$ were present in a higher proportion. The cultures grown at the same growth rate $\left(0.2 \mathrm{~h}^{-1}\right)$ did not show noticeable difference either in the mean and mode cell size or in the size distribution regardless of the presence of IPA.

However, the influence of the abnormal morphological changes became clearly visible when comparing the DCW measurements with the inline measured $\Delta \mathrm{C}$ and the critical frequency (see Figure 6 in Paper IV). The cultivations with similar DCW showed unexpected signals in $\Delta C$ : the cultures with high DCW (grown uninduced at $0.3 \mathrm{~h}^{-1}$ ) had a much smaller $\Delta C$ than the ones with low DCW (induced grown at $0.1 \mathrm{~h}^{-1}$ ). 


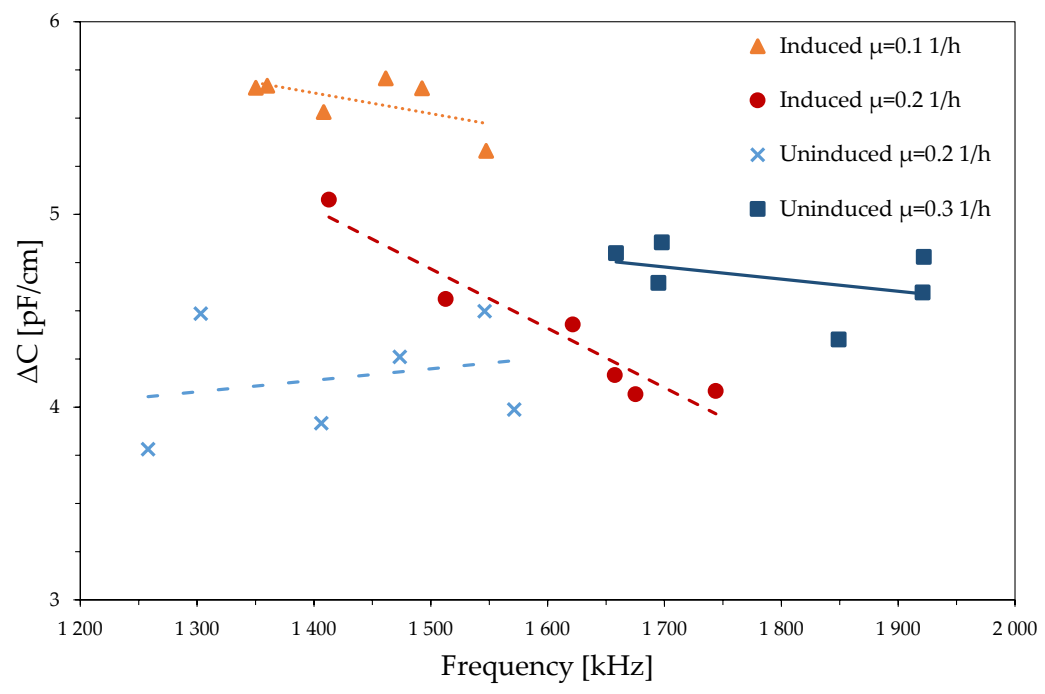

Figure 5.9: The correlation between the critical frequency and the capacitance increment where the lines show the fitted linear equations. (Redrawn from Paper IV.)

The capacitance increment of the uninduced cells revealed only a slight dependency of the critical frequency even with increasing DCW, while the induced cells' capacitance increment was highly frequency dependent at similar DCWs (Figure 5.9). With the rise of $\Delta C$ the critical frequency decreased, and this effect was stronger for the induced cultivation growing at higher growth rate.

These measurements also suggested that the capacitance spectra of the induced cells were strongly modified by the morphological changes observed under the light microscope.

The two presented studies on morphological abnormalities emphasize the importance of gaining deeper understanding of the cells' biological properties by combining different monitoring methods in parallel with the initiatives highlighted by PAT. The widened insight on the behaviour of the cells - including the morphological changes due to e.g. recombinant protein production - not only contributes to the expansion of existing knowledge but also points out the difficulties and challenges of the existing monitoring methods not yet discovered or solved today. 
5.3. A concept to advanced bioprocess control: absorbance sensor for monitoring and control the growth of biomass in a bioreactor

\subsection{A concept to advanced bioprocess control: absorbance sensor for monitoring and control the growth of biomass in a bioreactor}

Another two of the important cell-related CPPs are the concentration and the growth rate $(\mu)$ of the cells. This explains the driving force that led to the wide variety of techniques available to detect these parameters: several spectroscopic techniques (NIR, Raman and fluorescent), capacitance sensor, flow cytometry and microscopy [8791]. Although these techniques are excellent to monitor the cells in-line, several factors such as high investment cost, complicated calibration procedure and extensive data analysis make some of them less appealing for industrial implementation.

The spectroscopic methods meet all the requirements set for good monitoring in industrial applications: they are in situ, provide data close to real-time and fit the increasing need of flexibility by their ability to adapt to any production processes from bacteria to mammalian cells $[92,93]$.

The turbidity sensors are robust and sensitive in situ techniques for optical density (OD) measurements. In the experiments described in Paper III, a NIR transmission turbidity sensor was used to monitor the cell growth at $880 \mathrm{~nm}$. This sensor, immersed into the culture medium, measures the transmitted light within a fixed optical path (Figure 5.10). This optical arrangement results in a linear correlation with the cell density in lower concentration ranges. In another design of the turbidity sensor, the back-scattered light from the cell suspension is measured at an angle of $180^{\circ}$ which allows a broader detection range and is therefore suitable for higher cell concentrations [94, 95].

Transmission turbidity sensors use the Beer-Lambert law (Eq. 5.7) to establish a correlation between the measured absorbance $(A)$ and the concentration of the analyte $(c)$ depending on the length of the optical path $(l)$ where the measurement takes place:

$$
A=\varepsilon \cdot c \cdot l
$$

where $\varepsilon$ is the molar attenuation coefficient, describing how strongly the cells attenuate light at a given wavelength. 


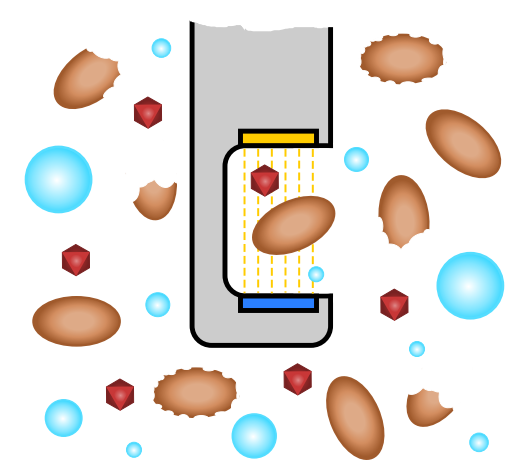

Figure 5.10: The principle of the transmission turbidity sensor showing the LED light source (yellow) and the detector (blue) with all the measured components in the reactor in colour, including solid media particles (red), cell debris, live and dead cells (brown), and air bubbles (light blue).

In Paper III, the investigation of a turbidity sensor's applicability for monitoring is demonstrated. Before implementing the turbidity sensor for biomass monitoring, all parameters interfering with the sensor signal were carefully evaluated from process perspective (Table 5.1). During the experiments, a homogenous medium was used to cultivate E. coli cells at aerobic conditions; thus the dominating interference was the air bubbles present in the medium.

One of the components affecting the bubbles in the medium was the added antifoam agent which reduces foaming through decreasing the surface tension of the air/media interface. Its effect was minimized by lowering the concentration and the dosage of the agent.

Another parameter significantly influencing both the concentration and the size of the bubbles present in the medium was the stirrer speed. To determine the effect of the aeration on the sensor signal, test experiments were performed in which the stirrer speed was adjusted stepwise at constant airflow, and the transition in the absorbance signal was examined both in culture and cell-free media. 
5.3. A concept to advanced bioprocess control: absorbance sensor for monitoring and control the growth of biomass in a bioreactor

Table 5.1: Interferences affecting the sensor signal and recommended actions to reduce them.

\begin{tabular}{l|l} 
Interferences & Recommended actions \\
\hline Solid media components & Use of homogenous media \\
Air bubbles & $\begin{array}{l}\text { Use of constant airflow } \\
\text { Investigate influence of reactor parameters by } \\
\text { the bubble size and concentration in the media } \\
\text { (airflow, stirrer speed, antifoam) }\end{array}$ \\
Dead cells, cell debris & $\begin{array}{l}\text { Use of cell strains where concentrations of } \\
\text { non-living cells are minor or unimportant (e.g. } \\
\text { bacteria) } \\
\text { Use a complementary measurement technique } \\
\text { that provides information on concentration of } \\
\text { living cells only }\end{array}$
\end{tabular}

In the cell-free media, the effect of the bubble concentration and size had higher impact than the measurements done in culture (see Figure 2 in Paper III). The cells in the culture influence the oxygen transfer by shifting the DO equilibrium through their respiration and by interfering with the bubble break-up and coalescence [96]. This caused a decrease in the number of larger bubbles and by that reduced the effect on the sensor signal. At the highest applied stirrer speed and biomass concentration during a fed-batch cultivation, the maximum error caused by the adjustment of the stirrer speed was determined to be $2 \%$. This error was important to consider when judging the performance of feedback controller and was therefore included in the margin of the setpoint value (see below).

After evaluating the impact of the disturbances on the sensor signal, the sensor was ready to be implemented into the system. As a next step, the settings of the signal processing were tested (Figure 5.11). Applying the raw sensor signal (RS) as input for a controller is generally not advised due to the high risk of oscillation in the controller caused by the sensor 
noise. When applying a noise filter (NF), it is important then to choose a high enough filtration to eliminate most of the noise, but not too high which would smoothen out the true signal, cause extensive delays or become unable to capture the dynamics of the process.

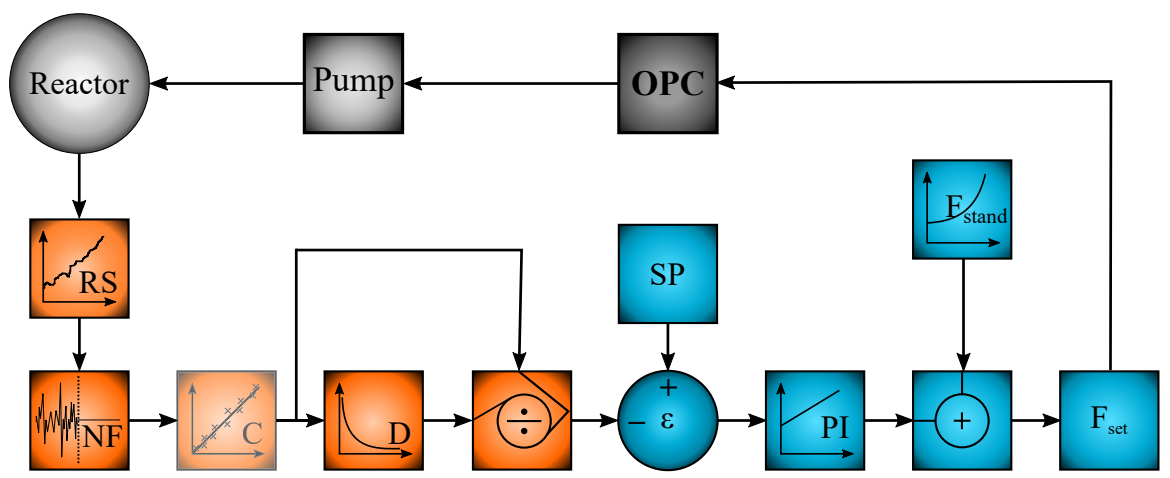

Figure 5.11: The setup of the system including the reactor and the pump (grey), the Open Platform Communications (OPC) (black), the signal processing steps (orange) and the controller (blue). The raw signal (RS) provided by the sensor was filtered (NF), correlated to DCW (C) and its derivative (D) was compared to the setpoint (SP) to calculate the error $(\varepsilon)$. This was used as the input for the feedback controller (PI) to adjust the standard feed profile $\left(\mathrm{F}_{\text {stand }}\right)$ defined by the feed-forward loop. The set feed rate $\left(\mathrm{F}_{\text {set }}\right)$ was then forwarded through an OPC system to the pump which pumped the set amount of feed into the reactor. (Redrawn from Paper III.)

A common way to convert the measured signal to growth rate is to correlate $(\mathrm{C})$ the absorbance signal to off-line measurements, such as DCW or viable cell number. Although a point-by-point correlation table with linear regression between the available correlation measurements is sometimes used for monitoring, it can easily result in unexpected spikes when used for control and lead to oscillation in the controller output. To avoid the oscillations, continuous correlation (e.g. second order equation) is the preferable method when the signal is further utilized in a feedback controller.

But in cases where the sensor signal drifts significantly over time, not even a continuous correlation can provide an accurate enough signal and the use of any correlation must be avoided. In Paper III, a possible solution was to use the signal derivative (D) instead, as the derivative of the absorbance from the turbidity sensor showed acceptable linearity with the specific growth rate. Thus, the instability of the controller 
5.3. A concept to advanced bioprocess control: absorbance sensor for monitoring and control the growth of biomass in a bioreactor

caused by the signal drift was reduced.

The derivative-based signal was compared with the setpoint value to calculate the error $(\varepsilon)$ used as the input to a feedback PI controller (PI). As mentioned previously, the non-linearity of the biological systems makes it difficult to control them by a stand-alone PI controller. To deal with the non-linearity, a feed-forward loop was also implemented into the controller which determined the exponential feeding scheme or trajectory for the growth of the cells. The standard feed rate $\left(\mathrm{F}_{\text {stand }}\right)$ was calculated by

$$
F(t)=F_{0} \cdot e^{\mu \cdot t}
$$

and

$$
F_{0}=X_{0} \cdot \frac{V_{\text {reactor }}}{Y_{X / S}} \cdot \frac{\rho_{\text {feed }}}{c_{\text {feed }}} \cdot \frac{\mu}{\ln 2^{\prime}}
$$

where $X_{0}$ is the DCW of the last sample of the batch phase, $V_{\text {reactor }}$ is the volume of the media, $Y_{X / S}$ is the biomass yield based on glucose, $\rho_{\text {feed }}$ is the density of the feed solution, the $c_{\text {feed }}$ is the glucose concentration of the feed solution and $\mu$ is the specific growth rate defined by the setpoint.

The standard feed was responsible for providing the dynamics of the culture; thus, the feedback PI controller only had to manage the deviations from this standard feed. Subsequently, the combined controller was more stable than a stand-alone PI controller would have been, and it was able to react to the disturbances within the bioreactor that a feed-forward feeding scheme could not have fulfilled.

The controller using the derivative of the absorbance signal from the turbidity sensor displayed satisfactory control of the recombinant protein production process by maintaining the desired specific growth rate in the culture (Figure 5.12). 


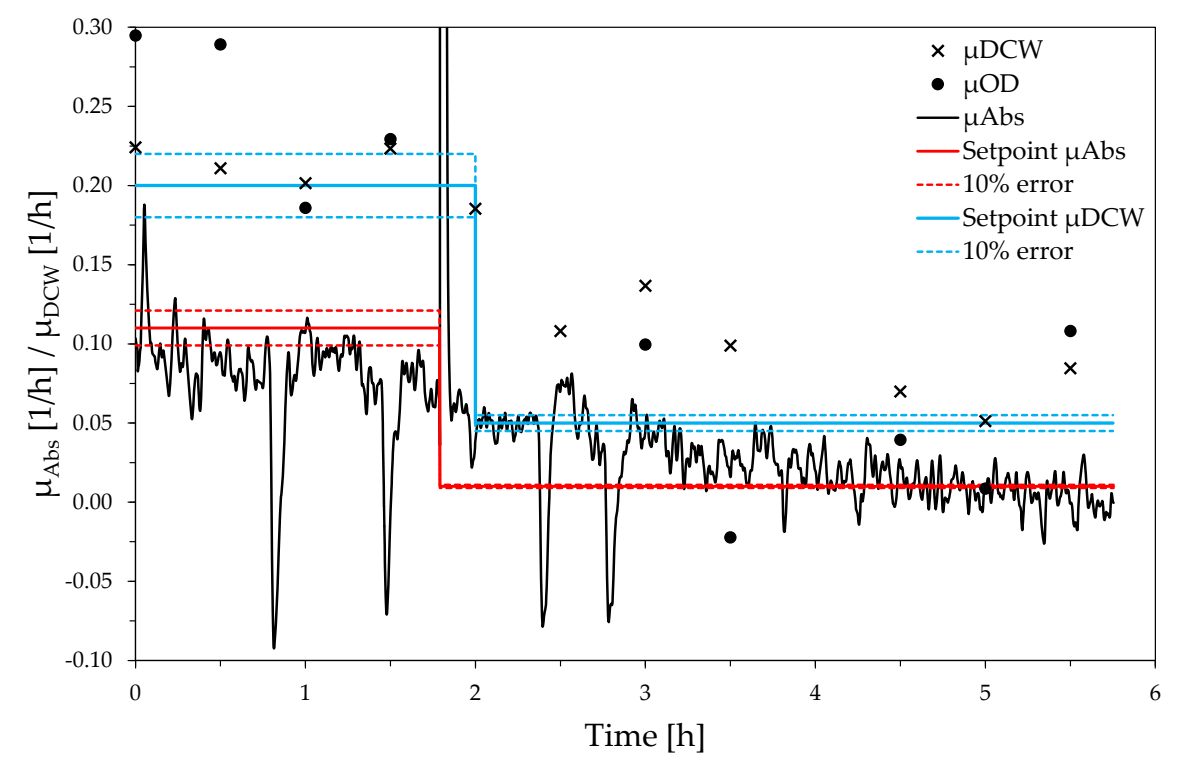

Figure 5.12: The change in the absorbance derivative-based signal $\left(\mu_{\mathrm{Abs}}\right.$, solid black line) in comparison to the growth rate based on off-line DCW $\left(\mu_{D C W}\right.$, crosses) and $\mathrm{OD}_{600}\left(\mu_{\mathrm{OD}}\right.$, dots) measurements and to the setpoints. The absorbance derivative had a different setpoint (red) from the desired growth rate setpoint (blue). Both setpoints had a 10\% error margin (dashed lines). (Redrawn from Paper III.)

This controller concept in Paper III was designed to focus on the simplicity, flexibility and adaptability of the turbidity sensor for implementation in an industrial environment. By using already existing feed-forward controller and upgrading it with a user-friendly, easy-to-set-up PI controller, more accurate adjustments of feeding rate become possible through compensating for unexpected disturbances in the fed-batch culture. The described controller setup can be used not only in stainless-steel bioreactors, but also in single-use bioreactor bags with other commercially available sensor alternatives, for example a capacitance sensor.

The CPPs and CQAs monitored and controlled by the techniques described in this chapter mirror many of the needs of the field. The presented research in Paper II-V, besides highlighting the importance of monitoring and control as described in the PAT initiative, also emphasize the difficulties and challenges of these state-of-the-art 
5.3. A concept to advanced bioprocess control: absorbance sensor for monitoring and control the growth of biomass in a bioreactor

monitoring techniques when implemented and applied in upstream bioprocessing: the difficulty of calibration, the disturbances by the cells and media components and the problems with sensor instability. 



\section{Chapter 6}

\section{Conclusion and future perspectives}

Gaining deeper understanding of the bioprocesses not only widens the existing knowledge but contributes to safe and stable product quality. This additional information also drives the development of new monitoring techniques and control systems, and the improvement of already existing techniques.

As emphasised in the PAT initiative, deeper understanding can only be reached by adhering to the paradigm of following the consecutive steps of design-analyse-control. Implementing the most resourceful and appropriate sensor for its purpose is the enabling action for reaching this goal. Reviewing the available sensor alternatives, classifying them based on the needs and requirements of the process, and prioritizing them depending on their analytical performances and costs are the key steps during process design. Paper I presents these steps and highlights the additional considerations that should be taken into account before selecting a monitoring technique.

The monitoring tools described in Paper II-V take this further to the analysing step of the PAT paradigm, by offering solutions to the highlighted challenges originated from the ambivalent needs of the various cultures used in the experimental work of this thesis and by monitoring the identified CPPs.

The slow growing mammalian cells producing a high value product do not necessarily require an in-line sensor for monitoring the metabolite formation of the cells. Single-use biosensor solutions, as the one 
developed and used in Paper V, provide fast and cheap alternatives to in-line sensors for metabolite monitoring and process decisions.

On the contrary, fast-growing cells, such as bacteria and yeast, cannot manage without in-line monitoring techniques as the measurements must to be able to keep up with the speed of the process.

The in-line capacitance sensor can, in addition to biomass concentration monitoring, also identify morphological changes of cells, as it is described in Paper II and IV.

The final control step of PAT paradigm is implemented in Paper III where a controller concept is outlined using a turbidity sensor to control the specific growth rate of cells in recombinant protein production.

All sensors and concepts used in this thesis could be developped further: the screen-printed biosensor could be integrated with different enzymes to measure other metabolites, nutrients or even product; the capacitance sensor could be integrated with a model describing the effect of morphological changes of cells with different shapes; the NIR sensor in the controller concept could be either substituted or supplemented with sensor alternatives, such as the previously mentioned capacitance sensor to obtain more cell-realted information on the processes.

Although all the experimental work that is presented in this thesis has been performed in stainless-steel bioreactors, all the sensors used for monitoring (Papers II, IV and V) and control (Paper III) can be implemented in single-use bioreactors. While some of the presented sensors, such as the screen-printed lactate sensor and the capacitance sensor are ready-to-use solutions, the controller approach should be adapted to be used with bioreactor bags.

In future development of monitoring techniques and control systems for media- and cell-related CPPs, flexibility is no longer only required in terms of processes, but also in adaptation to various bioreactor types, to be able meet the needs of this rapidly improving area. 


\section{References}

[1] F. E. Young. Biotechnology: the view from the FDA. Health Matrix, 4(3): 10-15, 1986.

[2] A. L. Demain and P. Vaishnav. Production of recombinant proteins by microbes and higher organisms. Biotechnology advances, 27(3): 297-306, 2009.

[3] O. Paliy and T. S. Gunasekera. Growth of E. coli BL21 in minimal media with different gluconeogenic carbon sources and salt contents. Applied microbiology and biotechnology, 73(5): 1169-1172, 2007.

[4] P. Cornelis. Expressing genes in different Escherichia coli compartments. Current opinion in biotechnology, 11(5): 450-454, 2000 .

[5] D. V. Goeddel, D. G. Kleid, F. Bolivar, H. L. Heyneker, D. G. Yansura, R. Crea, T. Hirose, A. Kraszewski, K. Itakura, and A. D. Riggs. Expression in Escherichia coli of chemically synthesized genes for human insulin. Proceedings of the National Academy of Sciences, 76(1): 106-110, 1979.

[6] K. Graumann and A. Premstaller. Manufacturing of recombinant therapeutic proteins in microbial systems. Biotechnology Journal: Healthcare Nutrition Technology, 1(2): 164-186, 2006.

[7] G. Striedner, I. Pfaffenzeller, L. Markus, S. Nemecek, R. Grabherr, and K. Bayer. Plasmid-free T7-based Escherichia coli expression systems. Biotechnology and bioengineering, 105(4): 786-794, 2010. 
[8] D. Porro, B. Gasser, T. Fossati, M. Maurer, P. Branduardi, M. Sauer, and D. Mattanovich. Production of recombinant proteins and metabolites in yeasts. Applied microbiology and biotechnology, 89(4): 939-948, 2011.

[9] R. Levy, K. Ahluwalia, D. J. Bohmann, H. M. Giang, L. J. Schwimmer, H. Issafras, N. B. Reddy, C. Chan, A. H. Horwitz, and T. Takeuchi. Enhancement of antibody fragment secretion into the Escherichia coli periplasm by co-expression with the peptidyl prolyl isomerase, FkpA, in the cytoplasm. Journal of immunological methods, 394(1-2): 10-21, 2013.

[10] O. Spadiut, S. Capone, F. Krainer, A. Glieder, and C. Herwig. Microbials for the production of monoclonal antibodies and antibody fragments. Trends in biotechnology, 32(1): 54-60, 2014.

[11] A. B. Lindner, R. Madden, A. Demarez, E. J. Stewart, and F. Taddei. Asymmetric segregation of protein aggregates is associated with cellular aging and rejuvenation. Proceedings of the National Academy of Sciences, 105(8): 3076-3081, 2008.

[12] S. Cho, D. Choe, E. Lee, S. C. Kim, B. Palsson, and B.-K. Cho. High-level dCas9 expression induces abnormal cell morphology in Escherichia coli. ACS synthetic biology, 7(4): 1085-1094, 2018.

[13] K. J. Jeong and S. Y. Lee. Enhanced production of recombinant proteins in Escherichia coli by filamentation suppression. Appl. Environ. Microbiol. 69(2): 1295-1298, 2003.

[14] K. K. Lee, C. S. Jang, J. Y. Yoon, S. Y. Kim, T. H. Kim, K. H. Ryu, and W. Kim. Abnormal cell division caused by inclusion bodies in E. coli; increased resistance against external stress. Microbiological research, 163(4): 394-402, 2008.

[15] J. Bos, Q. Zhang, S. Vyawahare, E. Rogers, S. M. Rosenberg, and R. H. Austin. Emergence of antibiotic resistance from multinucleated bacterial filaments. Proceedings of the National Academy of Sciences, 112(1): 178-183, 2015. 
[16] M. Knop. Yeast cell morphology and sexual reproduction-A short overview and some considerations. Comptes rendus biologies, 334(8-9): 599-606, 2011.

[17] P. L. Pratt, J. H. Bryce, and G. G. Stewart. The effects of osmotic pressure and ethanol on yeast viability and morphology. Journal of the Institute of Brewing, 109(3): 218-228, 2003.

[18] S. R. Ceccato-Antonini and P. E. Sudbery. Filamentous growth in Saccharomyces cerevisiae. Brazilian Journal of Microbiology, 35(3): 173-181, 2004.

[19] F. M. Wurm. Production of recombinant protein therapeutics in cultivated mammalian cells. Nature biotechnology, 22(11): 13931398, 2004.

[20] B. C. Mulukutla, S. Khan, A. Lange, and W.-S. Hu. Glucose metabolism in mammalian cell culture: new insights for tweaking vintage pathways. Trends in biotechnology, 28(9): 476-484, 2010.

[21] C. Altamirano, A. Illanes, S. Becerra, J. J. Cairó, and F. Gòdia. Considerations on the lactate consumption by $\mathrm{CHO}$ cells in the presence of galactose. Journal of biotechnology, 125(4): 547-556, 2006.

[22] A. Gambhir, A. F. Europa, and W.-S. Hu. Alteration of cellular metabolism by consecutive fed-batch cultures of mammalian cells. Journal of bioscience and bioengineering, 87(6): 805-810, 1999.

[23] R. V. Datar, T. Cartwright, and C.-G. Rosen. Process economics of animal cell and bacterial fermentations: a case study analysis of tissue plasminogen activator. Bio/technology, 11(3): 349-357, 1993.

[24] L. Grillberger, T. R. Kreil, S. Nasr, and M. Reiter. Emerging trends in plasma-free manufacturing of recombinant protein therapeutics expressed in mammalian cells. Biotechnology journal, 4(2): 186-201, 2009. 
[25] G. Walsh. Emerging trends in plasma-free manufacturing of recombinant protein therapeutics expressed in mammalian cells. Nature Biotechnology, 36: 1136-1145, 2018.

[26] C. Bisbee. Current perspectives on manufacturing and scaleup of biopharmaceuticals. Genetic Engineering and Biotechnology News, 13: 8-10, 1993.

[27] E. Yu. High-yield mAb expression: ACE system testing and process development. Abstract, BIOT, 239: 114, 2006.

[28] P. Doran. Bioprocess Engineering Principles. 2nd. Elsevier Ltd, Academic Press, 2013. Chap. 14: Reactor Engineering: 761-852.

[29] N. K. Tripathi. Production and purification of recombinant proteins from textitEscherichia coli. ChemBioEng Reviews, 3(3): 116-133, 2016.

[30] A. A. Shukla and U. Gottschalk. Single-use disposable technologies for biopharmaceutical manufacturing. Trends in biotechnology, 31(3): 147-154, 2013.

[31] A. S. Rathore. Follow-on protein products: scientific issues, developments and challenges. Trends in biotechnology, 27(12): 698705, 2009.

[32] E. Abrahams, G. S. Ginsburg, and M. Silver. The personalized medicine coalition. American Journal of Pharmacogenomics, 5(6): 345-355, 2005.

[33] J. J. Lewin III, E. J. Choi, and G. Ling. Pharmacy on demand: New technologies to enable miniaturized and mobile drug manufacturing. American Journal of Health-System Pharmacy, 73(2): 45-54, 2016.

[34] U. Gottschalk, K. Brorson, and A. A. Shukla. Innovation in biomanufacturing: the only way forward. Pharmaceutical bioprocessing, 1(2): 141-157, 2013. 
[35] U. Gottschalk, K. Brorson, and A. A. Shukla. The need for innovation in biomanufacturing. Nature biotechnology, 30(6): 489492, 2012.

[36] FDA. Guidance for industry, PAT - A Framework for Innovative Pharmaceutical Development, Manufacturing and Quality Assurance. $h t t p: / / w w w . f d a . g o v / c d e r / g u i d a n c e / p u b l i s h e d . h t m l, 2004$.

[37] J. Glassey, K. V. Gernaey, C. Clemens, T. W. Schulz, R. Oliveira, G. Striedner, and C.-F. Mandenius. Process analytical technology (PAT) for biopharmaceuticals. Biotechnology Journal, 6(4): 369-377, 2011.

[38] E. Read, J. Park, R. Shah, B. Riley, K. Brorson, and A. Rathore. Process analytical technology (PAT) for biopharmaceutical products: Part I. Concepts and applications. Biotechnology and bioengineering, 105(2): 276-284, 2010.

[39] E. Read, J. Park, R. Shah, B. Riley, K. Brorson, and A. Rathore. Process analytical technology (PAT) for biopharmaceutical products: Part II. Concepts and applications. Biotechnology and bioengineering, 105(2): 285-295, 2010.

[40] A. Rathore, R. Bhambure, and V. Ghare. Process analytical technology (PAT) for biopharmaceutical products. Analytical and bioanalytical chemistry, 398(1): 137-154, 2010.

[41] A. S. Rathore, M. Yu, S. Yeboah, and A. Sharma. Case study and application of process analytical technology (PAT) towards bioprocessing: Use of on-line high-performance liquid chromatography (HPLC) for making real-time pooling decisions for process chromatography. Biotechnology and bioengineering, 100(2): 306-316, 2008.

[42] A. Singh, V. Upadhyay, A. K. Upadhyay, S. M. Singh, and A. K. Panda. Protein recovery from inclusion bodies of Escherichia coli using mild solubilization process. Microbial cell factories, 14(1): 41, 2015. 
[43] P. Biechele, C. Busse, D. Solle, T. Scheper, and K. Reardon. Sensor systems for bioprocess monitoring. Engineering in Life sciences, 15(5): 469-488, 2015.

[44] C. Boero, M. A. Casulli, J. Olivo, L. Foglia, E. Orso, M. Mazza, S. Carrara, and G. De Micheli. Design, development, and validation of an in-situ biosensor array for metabolite monitoring of cell cultures. Biosensors and Bioelectronics, 61: 251-259, 2014.

[45] J. Claßen, F. Aupert, K. F. Reardon, D. Solle, and T. Scheper. Spectroscopic sensors for in-line bioprocess monitoring in research and pharmaceutical industrial application. Analytical and bioanalytical chemistry, 409(3): 651-666, 2017.

[46] R. Gustavsson and C.-F. Mandenius. Soft sensor control of metabolic fluxes in a recombinant Escherichia coli fed-batch cultivation producing green fluorescence protein. Bioprocess and biosystems engineering, 36(10): 1375-1384, 2013.

[47] K. Braasch, M. Nikolic-Jaric, T. Cabel, E. Salimi, G. E. Bridges, D. J. Thomson, and M. Butler. The changing dielectric properties of $\mathrm{CHO}$ cells can be used to determine early apoptotic events in a bioprocess. Biotechnology and bioengineering, 110(11): 2902-2914, 2013.

[48] S. Marose, C. Lindemann, R. Ulber, and T. Scheper. Optical sensor systems for bioprocess monitoring. Trends in Biotechnology, 17(1): 30-34, 1999.

[49] J. Randek and C.-F. Mandenius. On-line soft sensing in upstream bioprocessing. Critical reviews in biotechnology, 38(1): 106-121, 2018.

[50] S. Y. Lee. High cell-density culture of Escherichia coli. Trends in biotechnology, 14(3): 98-105, 1996. 
[51] M. Jenzsch, S. Gnoth, M. Beck, M. Kleinschmidt, R. Simutis, and A. Lübbert. Open-loop control of the biomass concentration within the growth phase of recombinant protein production processes. Journal of biotechnology, 127(1): 84-94, 2006.

[52] R. Oliveira, R. Simutis, and S. F. de Azevedo. Design of a stable adaptive controller for driving aerobic fermentation processes near maximum oxygen transfer capacity. Journal of Process Control, 14(6): 617-626, 2004.

[53] P. Wechselberger, P. Sagmeister, H. Engelking, T. Schmidt, J. Wenger, and C. Herwig. Efficient feeding profile optimization for recombinant protein production using physiological information. Bioprocess and biosystems engineering, 35(9): 1637-1649, 2012.

[54] M. Gao, Y. Tashiro, Q. Wang, K. Sakai, and K. Sonomoto. High acetone-butanol-ethanol production in $\mathrm{pH}$-stat co-feeding of acetate and glucose. Journal of bioscience and bioengineering, 122(2): 176-182, 2016.

[55] M. Jenzsch, S. Gnoth, M. Kleinschmidt, R. Simutis, and A. Lübbert. Improving the batch-to-batch reproducibility in microbial cultures during recombinant protein production by guiding the process along a predefined total biomass profile. Bioprocess and biosystems engineering, 29(5-6): 315-321, 2006.

[56] M. Jenzsch, S. Gnoth, M. Kleinschmidt, R. Simutis, and A. Lübbert. Improving the batch-to-batch reproducibility of microbial cultures during recombinant protein production by regulation of the total carbon dioxide production. Journal of biotechnology, 128(4): 858-867, 2007.

[57] R. Oliveira, J. Clemente, A. Cunha, and M. Carrondo. Adaptive dissolved oxygen control through the glycerol feeding in a recombinant Pichia pastoris cultivation in conditions of oxygen transfer limitation. Journal of biotechnology, 116(1): 35-50, 2005. 
[58] S. Craven, J. Whelan, and B. Glennon. Glucose concentration control of a fed-batch mammalian cell bioprocess using a nonlinear model predictive controller. Journal of Process Control, 24(4): 344-357, 2014.

[59] J. Lee, S. Y. Lee, S. Park, and A. P. Middelberg. Control of fedbatch fermentations. Biotechnology advances, 17(1): 29-48, 1999.

[60] P. A. L. Pérez, R. A. López, and R. Femat. Control in Bioprocessing: Modeling, Estimation and the Use of Soft Sensors. John Wiley \& Sons, 2020.

[61] B. W. Bequette. Process control: modeling, design, and simulation. Prentice Hall Professional, 2003.

[62] J. S. Alford. Bioprocess control: Advances and challenges. Computers \& Chemical Engineering, 30(10-12): 1464-1475, 2006.

[63] J. Gomes, V. Chopda, and A. S. Rathore. Monitoring and control of bioreactor: basic concepts and recent advances. Bioprocessing Technology for Production of Biopharmaceuticals and Bioproducts, 201237, 2018.

[64] EMA. Guideline on process validation for finished products-Information and data to be provided in regulatory submissions. https://www.ema.europa.eu/en/documents/scientificguideline/guideline-process-validation-finished-productsinformation-data-be-provided-regulatory-submissions_en.pdf.

[65] F. Arduini, S. Cinti, V. Scognamiglio, D. Moscone, and G. Palleschi. How cutting-edge technologies impact the design of electrochemical (bio) sensors for environmental analysis. A review. Analytica chimica acta, 959: 15-42, 2017.

[66] P. N. Bartlett. Bioelectrochemistry: fundamentals, experimental techniques and applications. John Wiley \& Sons, 2008.

[67] L. Rassaei, W. Olthuis, S. Tsujimura, E. J. Sudhölter, and A. van den Berg. Lactate biosensors: current status and outlook. Analytical and bioanalytical chemistry, 406(1): 123-137, 2014. 
[68] K. Rathee, V. Dhull, R. Dhull, and S. Singh. Biosensors based on electrochemical lactate detection: A comprehensive review. Biochemistry and biophysics reports, 5: 35-54, 2016.

[69] F. Zagari, M. Jordan, M. Stettler, H. Broly, and F. M. Wurm. Lactate metabolism shift in $\mathrm{CHO}$ cell culture: the role of mitochondrial oxidative activity. New biotechnology, 30(2): 238245, 2013.

[70] L. Theuer, J. Randek, S. Junne, P. Neubauer, C.-F. Mandenius, and V. Beni. Single-Use Printed Biosensor for L-Lactate and Its Application in Bioprocess Monitoring. Processes, 8(3): 321, 2020.

[71] A. Bluma, T. Höpfner, P. Lindner, C. Rehbock, S. Beutel, D. Riechers, B. Hitzmann, and T. Scheper. In-situ imaging sensors for bioprocess monitoring: state of the art. Analytical and bioanalytical chemistry, 398(6): 2429-2438, 2010.

[72] T. Scheper, J. Hilmer, F. Lammers, C. Müller, and M. Reinecke. Biosensors in bioprocess monitoring. Journal of Chromatography A, 725(1): 3-12, 1996.

[73] J. P. Carvell and J. E. Dowd. On-line measurements and control of viable cell density in cell culture manufacturing processes using radio-frequency impedance. Cytotechnology, 50(1-3): 35, 2006.

[74] C. Justice, A. Brix, D. Freimark, M. Kraume, P. Pfromm, B. Eichenmueller, and P. Czermak. Process control in cell culture technology using dielectric spectroscopy. Biotechnology advances, 29(4): 391-401, 2011.

[75] P. Kroll, I. V. Stelzer, and C. Herwig. Soft sensor for monitoring biomass subpopulations in mammalian cell culture processes. Biotechnology letters, 39(11): 1667-1673, 2017.

[76] C. M. Harris, R. W. Todd, S. J. Bungard, R. W. Lovitt, J. G. Morris, and D. B. Kell. Dielectric permittivity of microbial suspensions at radio frequencies: a novel method for the real-time estimation of 
microbial biomass. Enzyme and Microbial Technology, 9(3): 181-186, 1987.

[77] C. L. Davey and D. B. Kell. "The low-frequency dielectric properties of biological cells". Bioelectrochemistry of cells and tissues. Ed. by D. Walz, H. Berg, and G. Milazzo. Birkhäuser, 1995: pp. 159-207.

[78] K. S. Cole and R. H. Cole. Dispersion and absorption in dielectrics I. Alternating current characteristics. The Journal of chemical physics, 9(4): 341-351, 1941.

[79] G. H. Markx, C. L. Davey, and D. B. Kell. To what extent is the magnitude of the Cole-Cole $\alpha$ of the $\beta$-dielectric dispersion of cell suspensions explicable in terms of the cell size distribution? Bioelectrochemistry and bioenergetics, 25(2): 195-211, 1991.

[80] G. H. Markx and C. L. Davey. The dielectric properties of biological cells at radiofrequencies: applications in biotechnology. Enzyme and Microbial Technology, 25(3-5): 161-171, 1999.

[81] K. Asami and T. Yonezawa. Dielectric behavior of non-spherical cells in culture. Biochimica et Biophysica Acta (BBA)-General Subjects, 1245(3): 317-324, 1995.

[82] A. Di Biasio and C. Cametti. Effect of shape on the dielectric properties of biological cell suspensions. Bioelectrochemistry, 71(2): 149-156, 2007.

[83] A. Di Biasio, L. Ambrosone, and C. Cametti. The dielectric behavior of nonspherical biological cell suspensions: an analytic approach. Biophysical journal, 99(1): 163-174, 2010.

[84] K. Asami. Dielectric dispersion in biological cells of complex geometry simulated by the three-dimensional finite difference method. Journal of Physics D: Applied Physics, 39(3): 492, 2006. 
[85] J. E. Yardley, D. B. Kell, J. Barrett, and C. L. Davey. On-line, real-time measurements of cellular biomass using dielectric spectroscopy. Biotechnology and Genetic Engineering Reviews, 17(1): 3-36, 2000.

[86] J. Randek and C.-F. Mandenius. In situ scanning capacitance sensor with spectral analysis reveals morphological states in cultures for production of biopharmaceuticals. Sensors and Actuators B: Chemical, 313: 128052, 2020.

[87] S. A. Arnold, R. Gaensakoo, L. M. Harvey, and B. McNeil. Use of at-line and in-situ near-infrared spectroscopy to monitor biomass in an industrial fed-batch Escherichia coli process. Biotechnology and Bioengineering, 80(4): 405-413, 2002.

[88] T. Broger, R. P. Odermatt, P. Huber, and B. Sonnleitner. Realtime on-line flow cytometry for bioprocess monitoring. Journal of biotechnology, 154(4): 240-247, 2011.

[89] S. M. Faassen and B. Hitzmann. Fluorescence spectroscopy and chemometric modeling for bioprocess monitoring. Sensors, 15(5): 10271-10291, 2015.

[90] H. L. Lee, P. Boccazzi, N. Gorret, R. J. Ram, and A. J. Sinskey. In situ bioprocess monitoring of Escherichia coli bioreactions using Raman spectroscopy. Vibrational Spectroscopy, 35(1-2): 131-137, 2004.

[91] C. Luder, P. Lindner, D. Bulnes-Abundis, S. M. Lu, T. Lucking, D. Solle, and T. Scheper. In situ microscopy and MIR-spectroscopy as non-invasive optical sensors for cell cultivation process monitoring. Pharmaceutical Bioprocessing, 2(2): 157-166, 2014.

[92] S. André, L. Saint Cristau, S. Gaillard, O. Devos, É. Calvosa, and L. Duponchel. In-line and real-time prediction of recombinant antibody titer by in situ Raman spectroscopy. Analytica chimica acta, 892: 148-152, 2015. 
[93] D. Landgrebe, C. Haake, T. Höpfner, S. Beutel, B. Hitzmann, T. Scheper, M. Rhiel, and K. F. Reardon. On-line infrared spectroscopy for bioprocess monitoring. Applied microbiology and biotechnology, 88(1): 11-22, 2010.

[94] B. Junker, J. Reddy, K. Gbewonyo, and R. Greasham. On-line and in-situ monitoring technology for cell density measurement in microbial and animal cell cultures. Bioprocess Engineering, 10(5-6): 195-207, 1994.

[95] J. A. Myers, B. S. Curtis, and W. R. Curtis. Improving accuracy of cell and chromophore concentration measurements using optical density. BMC biophysics, 6(1): 4, 2013.

[96] P. Doran. Bioprocess Engineering Principles. 2nd. Elsevier Ltd, Academic Press, 2013. Chap. 10: Mass transfer: 379-444. 


\section{Corrections to the papers}

\section{Paper I.}

In Table 1., under the Needs and requirements in row 9 the analytical performance listed is Transferability instead of Tra0nsferability.

\section{Paper II.}

In the caption of Figure 2., the second sentence is: "Uninduced cultures are indicated with triangles $(\mathbf{\Lambda})$ and induced cultures with dots $(\bullet) . "$ instead of "Uninduced cultures are indicated with dots $(\bullet)$ and induced cultures with squares $(\mathbf{\Delta}) . "$ 


\section{Papers}

The papers associated with this thesis have been removed for copyright reasons. For more details about these see:

http://urn.kb.se/resolve?urn=urn:nbn:se:liu:diva-165116 


\section{FACULTY OF SCIENCE AND ENGINEERING}

Linköping Studies in Science and Technology, Dissertation No. 2056, 2020 Department of Physics, Chemistry and Biology

Linköping University

SE-581 83 Linköping, Sweden

\section{www.liu.se}

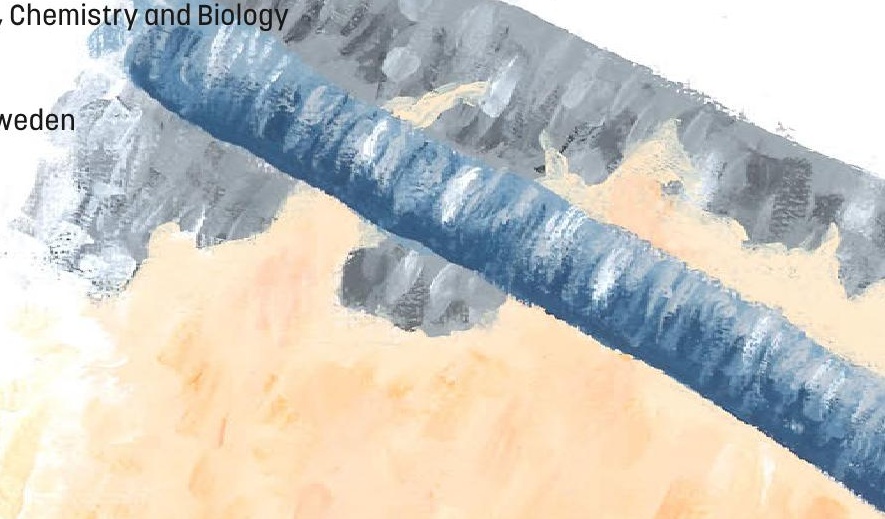

